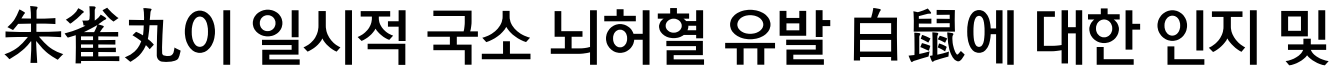 운동기능 회복에 미치는 효과
}

김보은, 강석봉*, 정대규

대구한의대학교 부속한방병원 한방신경정신과, 내과*

\section{The Recovery Effects of Joojakwhan - A Traditional Korean Medical Poly-herbal Drug for the Cognitions and Motor Functions in Mild Stroke Rat Model by Using Transient Middle Cerebral Artery Occlusion}

\author{
Bo-Eun Kim, Seok-Bong Kang*, Dae-Kyoo Chung \\ Departments of Oriental Neuropsychiatry, ${ }^{*}$ Oriental Internal Medicine, College of Oriental Medicine, Daegu Haany University
}

Received: November 13, 2013 Revised: December 9, 2013 Accepted: December 16, 2013

Correspondence to

Dae-Kyoo Chung

Department of Oriental

Neuropsychiatry, College of Oreintal Medicine, Daegu Hanny University,

Sang-dong Suseong-gu, Daegu, Korea

Tel: +82-53-770-2243

Fax: +82-53-770-2169

E-mail: hyunwol_@hanmail.net Acknowledgement

This study is included master's degree article of department of oriental neuropsychiatry of Daegu Hanny

Graduate School.
Objectives: The object of this study is to observe the cognition and motor function recovery effects of Joojakwhan (JJW), a traditional Korean poly-herbal formula for treating various neuropsychiatric diseases such as dementia, for the mildly stroke rats, with 60 minutes of reperfusion transient middle cerebral artery occlusion (tMCA0).

Methods: In the present study, 125, 250 and $500 \mathrm{mg} / \mathrm{kg}$ of JJW were orally administered, once per day for 10 continuous days 2 hours after the tMCAO. The body weight changes, infarct sizes under $2 \% 2$, 3, 5-triphenyl tetrazolium chloride (TC) stain, sensorimotor functions and cognitive motor behavior tests were serially monitored with cerebral caspase- 3 and cleaved poly (ADP-ribose) polymerase (PARP)-immunoreactivities and histopathological changes. The effects of tMCAO on sensorimotor functions were evaluated by using of limb placing and body-swing tests, and the cognitive motor behaviors were also observed with water maze tests.

Results: From the results of $\mathrm{MMCAO}$, with marked decreases of body weights, disorders of sensorimotor functions increases the limb placing test scores, and decrease the numbers and percentages of body swings to the ipsilateral sides. The cognitive motor behaviors increases the distances and time to reach the escape platform which included the inhibitions of the decreases with repeated trials that were observed with focal cerebral cortex infarct volumes. In addition, the marked increases of the atrophy, numbers of degeneration, caspase-3- and PARP-immunoreactive cells around peri-infarct ipsilateral cerebral cortex were also observed in IMCAO controls when compared with the sham control rats, respectively.

Conclusions: The results obtained from this study suggest that oral administrations of JJW indicate obvious cognitions and motor function recoveries of the rats with $\mathrm{MMCAO}$, mild strokes, which are mediated by neuro-protective effects through known antioxidant effects of components.

Key Words: Joojakwhan, Cognition and motor function recovery, Mild stroke. 


\section{I. 서론}

뇌졸중(stroke)은 전 세계적으로 심각한 후유증을 동반하 는 가장 흔한 질환 중 하나로1), 지난 30년간 연구자들은 뇌 졸중 후 동반되는 뇌손상과 인지 및 각종 기능장애를 극복 하기 위한 치료제 개발에 집중해 왔다 ${ }^{2,3)}$. 뇌허혈(腦虛血)에 의한 신경세포의 손상은 초기와 후기로 나누어지는데 초기 에는 대부분 뇌졸중에 의해 유발된 허혈(虛血)로 인해 일시적 혈관폐쇄가 일어나 산소부족으로 신경세포가 괴사하게 되고, 후기에는 재관류 후 활성산소에 의해 apoptosis, 즉 지연성 세포사(delayed neuronal death)가 일어나게 된다 ${ }^{4,5)}$. 따라 서 유리된 유해 활성 산소류에 의한 산화적 스트레(oxidative stress)가 허혈성 뇌손상의 주 원인으로 주목 받고 있으 며,7), 산화적 스트레스는 후기 재관류 후 유발되는 지연성 세포사에 관여하는 것으로 알려진 각종 염증의 중개물질로 도 작용하는 것으로 알려져 있고 ${ }^{8}$, 강력한 항산화 물질로 알려진 비타민(vitamin)과 각종 polyphenol 화합물에 의한 허혈성 뇌손상에 대한 신경보호 효과는 이미 잘 알려져 있 다 ${ }^{9-11)}$.

허혈성 신경세포 손상은 혈관성 치매의 주된 원인으로 ${ }^{12)}$ 다른 치매와 달리 예방과 치료에 가능성이 많은데도 불구하 고, 상대적으로 많은 연구가 이루어지지는 않고 있다 ${ }^{13)}$. 혈 관성 치매는 대부분 뇌졸중의 후속 질환으로 나타나므로 한 의학적 범주에서는 중풍(中風), 치매(癡呆), 건망(健忘) 등에 해당한다고 볼 수 있으며 ${ }^{14)}$, 원인으로는 심(心), 간(肝), 신 (腎)의 허(虛)와 풍(風), 화(火), 담 痰), 어(瘀)의 실(實)로 인 식하였다 ${ }^{15)}$.

주작환(朱雀丸, Joojakwhan; JJW)은 이천(李梴)의 《의 학입문(醫學入門)》 ${ }^{16}$ 에 처음 수록되어 있으며 마음과 정신 이 안정되지 못하고 건망증이 있으며 화(火)가 잘 내려가지 않아서 때때로 떨고 두근거리는 증상을 치료한다고 하였다. 현재까지 주작환(朱雀丸)의 구성 성분인 복신의 항산화 효 과에 의한 신경보호 및 치매 치료 효과 ${ }^{17-19)}$ 가 비교적 잘 알

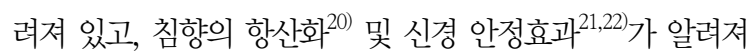
있으며, 인삼 또한 다양한 신경보호 및 치매 치료효과가 잘 알려져 있으나 ${ }^{23-25)}$, 주작환(朱雀丸) 자체에 대한 실험적 연 구는 잘 알려져 있지 않다.

따라서 본 연구에서는 주작환(朱雀丸)의 허혈성 뇌손상 에서 인지 및 운동기능 회복효과를 $\mathrm{tMCAO}$ (transient mid- dle cerebral artery occlusion) 백서를 이용하여 infarct 주 변부위의 대뇌 위축, 변성 신경세포의 수, caspase-3 및 cleaved poly (ADP-ribose) polymerase (PARP) 면역반응 신경세포의 수적 변화와 limb placing test ${ }^{26}$ 및 body swing test ${ }^{27)}$, water maze test ${ }^{28}$ 를 이용하여 인지 및 운동 기능 회복효과를 확인하고자 하였다.

\section{II. 재료 및 방법}

본 실험에 사용된 모든 실험동물은 "Guide for the Care and Use of Laboratory Animals [Department of Health, Education, and Welfare Publication (National Institute of Health) 85-23, 1985]에 기초한 대구한의대학교 동물윤 리위원회 동물 윤리기준에 준하여 취급하였다.

\section{1. 실험약재: 주작환(朱雀丸)}

본 실험에 사용된 약재는 대구한의대학교 부속한방병원 에서 매입한 것을 관능검사를 통하여 선정하여 사용 하였으 며, 본 실험에 사용된 주작환(朱雀丸, Joojakwhan; JJW)의 조성은 Table 1과 같다. 선정된 약제를 전기 미세분쇄기 (Sungchang Machine Co., Sungnam, Korea)로 세말하여, 옅은 갈색의 분말을 얻어 실험에 사용하였다. 준비한 주작 환(朱雀丸) 세말 분말은 $-20^{\circ} \mathrm{C}$ 의 냉장고에 보관 후 실험에 사용하였으며, 본 실험에서 사용한 용매인 멸균 증류수에 $100 \mathrm{mg} / \mathrm{ml}$ 의 농도까지 비교적 잘 현탁되었다.

\section{2. 실험동물 및 사양관리}

60마리의 수컷 Sprague-Dawely 백서(6-wk old upon receipt, SLC, Japan)를 24일의 순화과정을 거쳐 실험에 사 용하였으며, 순화과정 및 실험 전 기간 동안 온도 $\left(20 ~ 25^{\circ} \mathrm{C}\right)$ 와 습도(50 55\%)가 조절된 사육실에서 백서용 polycar-

Table 1. Composition of Joojakwhan Used in This Study

\begin{tabular}{llc}
\hline \multicolumn{1}{c}{ Herb } & \multicolumn{1}{c}{ Scientific name } & Weight $(\mathrm{g})$ \\
\hline Hoelen cum Radix White & Poria cocos Wolf & 80 \\
Aquilariae Lignum & Aquilaria agallocha Roxburgh & 20 \\
Ginseng Radix & Panax ginseng C.A.Meyer & 20 \\
Total & 3 types & 120 \\
\hline
\end{tabular}

All individual herbs were purchases from local voucher after confirm the morphology under microscopy by Pohang Oriental Hospital, Daegu Haany University (Pohang, Korea). 
Table 2. Experimental Design Used in This Study

\begin{tabular}{|c|c|c|c|}
\hline Group & Operation & $\begin{array}{l}\text { Group } \\
\text { identification }\end{array}$ & Treatment \\
\hline Control & Sham surgery & Sham control & Saline $5 \mathrm{ml} / \mathrm{kg} /$ day \\
\hline Control & tMCAO & tMCAO control & Saline 5 ml/kg/day \\
\hline Active & tMCAO & JJW 125 & JJW 125 mg/kg/day \\
\hline Active & tMCAO & JJW 250 & JJW 250 mg/kg/day \\
\hline Active & tMCAO & JJW 500 & JJW 500 mg/kg/day \\
\hline
\end{tabular}

Total 32 tMCAO- or 8 sham-operated rats (five groups; 8 rats per group) were selected base on the body weight and sensorimotor functions at 24 hrs after operation and were used in this experiment. Three different dosages of JJW were directly suspended in sterilized distilled water and orally administered in a volume of $5 \mathrm{ml} / \mathrm{kg}$, once a day for 10 days from 2 hrs after stabilization periods from tMCAO (after reperfusion). Sensorimotor function test - limb placing and body swing test were conducted at 1 day before operation (base line), 1, 3, 7 and 10 days after $\mathrm{AMCAO}$, respectively. Cognitive motor behavior, water maze test was conducted at 10 days after $\mathrm{MCAO}$, respectively. tMCAO: 60 min reperfusion transient Middle Cerebral Artery Occlusion, JJW: Joojakwhan grinded powders.

bonate 사육 상자에 5마리씩 수용하여 사육하였고, 명암 주 기(light : dark cycle)는 12시간 주기로 조절하였으며, 사 료(Samyang, Korea)와 음수는 자유롭게 공급하였다. tMCAO (transient middle cerebral artery occlusion) 수 술 24 시간 후 생존한 실험동물 중 신경운동학적 및 인지행 동 검사를 통하여, 유사한 이상 소견을 보이는 실험동물만 선정하여, 실험 군당 8마리씩 무작위 배치 시켜 실험에 사용 하였다. 또한 8마리의 위수술 동물을 선정하여, 위수술 대조 군으로 사용하였다. 모든 실험동물은 수술일 및 최종 부검 일에 각각 18 시간 정도 절식을 실시하였으며(이 기간에도 음수는 자유롭게 공급하였다), picric acid로 개체를 식별하 였다.

\section{3. 실험군 분리 및 약물의 투여}

실험동물은 군당 8마리씩 Table 2에 기록한 5그룹으로 구분하였다. 즉, 위수술을 실시한 후 멸균 증류수를 투여한 위수술 대조군(sham control), tMCAO 수술 후 멸균 증류 수를 투여한 $\mathrm{tMCAO}$ 대조군(tMCAO control), $\mathrm{tMCAO}$ 수 술 후 주작환(朱雀丸, Joojakwhan; JJW) $125 \mathrm{mg} / \mathrm{kg}$ (JJW 125), $250 \mathrm{mg} / \mathrm{kg}$ (JJW 250) 및 $500 \mathrm{mg} / \mathrm{kg}$ (JJW 500) 투 여군의 5 군으로 구분하여 실험하였다(Table 2). 주작환(朱 雀丸)은 멸균 증류수에 현탁시켜 동물 체중 $\mathrm{kg}$ 당 $5 \mathrm{ml}$ 의 용량으로 매일 1회씩 10일간 금속제 Zonde가 부착된 $3 \mathrm{ml}$ 주사기(syringe)를 이용하여, $\mathrm{tMCAO}$ 수술 2시간 후부터 강 제 경구 투여하였다.

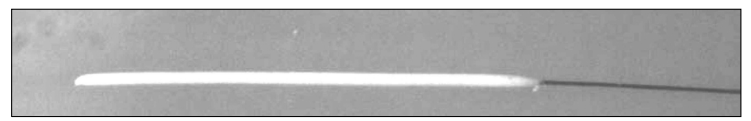

Fig. 1. 4-0 Silicon rubber-coated monofilaments used in this experiment. TMCAO was conducted using silicon rubber-coated monofilaments (4-0 fine MCAO suture L56 PK10; Doccol, Redlands, CA, USA), and blood reperfusion was achieved by withdrawing the suture from ECA at $1 \mathrm{hr}$ after MCAO.

tMCAO: 60 min reperfusion transient Middle Cerebral Artery Occlusion, ECA: External Carotid Artery.

\section{4. $\mathrm{tMCAO}$ 수술}

Mild stroke을 유발하기 위해 Longa 등(1989) $)^{29)}$ 이 언급 한 방법에 따라 $70 \% \mathrm{~N}_{2} \mathrm{O}$ 와 $28.5 \% \mathrm{O}_{2}$ 가스에 $1.5 \%$ isoflurane (Hana Pharm. Co., Hwasung, Korea)을 혼합한 마취가스로 전신마취를 시킨 후 수술대에 고정하여 놓고, 경부 피부절개를 통해, 미주신경과 우측 총경동맥, 외경동맥 및 내경동맥을 분리 노출시킨 다음, silicon rubber-coated monofilaments (4-0 fine MCAO suture L56 PK10; Doccol, Redlands, CA, USA; Fig. 1)를 외경동맥으로부터 내경동맥에 23 24 mm 정도 깊이로 삽입하여 내경동맥의 혈류를 일시적으로 차단하였다. 내경동맥 혈류 차단 60 분 후 monofilament을 제거하고 재관류시켜 $\mathrm{tMCAO}$ 을 완성 하였다. 흡입 전신마취 후 직장온도계와 열 패드를 이용하 여 체온을 일정하게 유지시켰으며, 전체적인 사망률은 5\% 이하(2마리)로 관찰되었다. Sham $\mathrm{MCAO}$ 는 $\mathrm{tMCAO}$ 에서와 동일한 방법으로 총경동맥, 내경동맥 및 외경동맥을 노출시 킨 다음 monofilament의 삽입 및 재관류를 실시하지 않고, 창강을 폐쇄하였다.

\section{5. 체중 측정}

모든 실험동물의 체중을 $\mathrm{tMCAO}$ 수술 1일전, $\mathrm{tMCAO}$ 수 술일(투여 시작일), $\mathrm{tMCAO}$ 수술 1, 2, 3, 7, 9 및 최종 희생 일에 각각 측정하였으며, 사료섭취에 따른 체중 변화를 최 소화하기 위해 $\mathrm{tMCAO}$ 수술일 및 최종 희생일에 모든 실험 동물은 18 시간 정도 절식시켰으며, 실험 시작시의 개체 차 이에 의한 체중 변화를 최소화하기 위해 하기의 공식 [1]을 이용하여 투여 시작일에서 투여 10 일 후까지의 체중 변화량 인 증체량 (body weight gains)을 산출하였다.

EQUATION [1]. Body Weight Gains (g) during 10 Days after tMCAO 
= (Body weight at the 10 days after tMCAO-body weight at the day of $\mathrm{tMCAO}$ )

\section{6. 신경학적 운동행동 검사}

$\mathrm{tMCAO}$ 에 의한 신경학적 운동행동 검사는 limb placing test $^{26)}$ 및 body swing 검사 ${ }^{27)}$ 를 이용하여 평가하였다. 신경 학적 운동행동 검사는 $\mathrm{tMCAO}$ 수술 1일 전 base line을 설 정하기 위해 실시하였으며, 이후 $\mathrm{tMCAO} \mathrm{1,} \mathrm{3,} 7$ 및 10일 후에 각각 약물 투여 전 실시하였다.

\section{1) Limb placing test}

평가시 관찰자가 실험군 및 실험동물의 개체 번호를 알지 못하도록 하여, 전지 및 후지에 대한 위치 이상 여부를 독립 적으로 각각 실시하였다. 전지에 대한 limb placing test를 위해 전지가 자유롭도록 실험동물의 몸통을 잡아, 실험대의 모서리 부분으로 천천히 움직이면서, 시각, 코털(vibrissae) 감각, 촉각 및 고유감각 등 4가지 감각에 대한 배치이상 유 무 검사를 실시하였다. 후지에 대해서는 동일한 방법으로 촉각 및 고유감각에 의한 배치 이상 유무를 검사하였다. 각 각의 감각에 대한 척도는 즉각적으로 정확하게 배치시키면 0점, 한쪽 발만 배치시키면 1점, 불완전하지만 2초 이상 지 연된 이후 배치시키면 2점, 반응이 없으면 3점을 주어, 전지 에 대한 limb placing test는 총점 0점을 정상으로, 12점을 최대 신경 장애 점수로 하였으며, 후지에 대한 검사에서는 총점 6점으로 검사를 수행하였다.

\section{2) Body swing test}

실험동물을 꼬리의 기시부에서 $2 \mathrm{~cm}$ 정도 떨어진 부분을 잡고 실험대에서부터 대략 $2 \mathrm{~cm}$ 정도 떨어지게 들어 올린 다음 수직선상에서 머리를 좌측 또는 우측으로 $10^{\circ}$ 이상 움 직인 경우를 body swing으로 간주하였다. 정상 동물에서 좌우 body swing의 비율이 대략 $1: 1$ 인 반면, 오른쪽 $\mathrm{tMCAO}$ 를 실시한 경우, 실험동물은 수술한 반대편, 좌측으 로만 body swing을 실시하는 경향을 나타내므로, 실험동물 당 총 30번의 body swing 동안 수술부위의 반대쪽인 왼쪽 으로의 body swing 횟수에 대한 수술부위인 오른쪽으로 body swing의 비율을 각각 산출하였다.

\section{7. 인지적 운동행동 검사}

실험동물의 인지행동의 이상 유무를 검사하기 위해, water maze tank test를 Morris (1984)의 방법 ${ }^{28}$ 에 따라 $\mathrm{tMCAO} 10$ 일 후 측정하였다. 모든 실험동물은 3회의 시도 를 통해 water maze tank $(150 \times 50 \mathrm{~cm})$ escape platform $(15 \times 30 \mathrm{~cm})$ 에 도달하기까지의 거리 및 시간을 측정하여, 인지 및 학습 능력의 변화를 관찰하였다. 즉, 검사장비는 직 경 $150 \mathrm{~cm}$, 높이가 $50 \mathrm{~cm}$ 인 원통형의 검은색 수조가 사용 되었고, 직경이 $15 \mathrm{~cm}$, 높이가 $30 \mathrm{~cm}$ 인 원형 탈출대 (escape platform)을 원통형 수조의 한 사분면의 중앙에 위 치시켰으며, 백서의 출발은 escape platform가 위치한 사 분면의 대각선 끝에서 실시하였다. 물은 탈출대가 수면으로 부터 $2 \mathrm{~cm}$ 아래에 잠길 정도로 채우고 물의 온도는 $22.0 \pm 1.0^{\circ} \mathrm{C}$ 를 유지하였다. 수조 안에서 움직이는 백서의 움직임을 a computer interfaced camera tracking system (Smart junior, PanLab, Barcelona, Spain)을 이용하 여 기록하였으며, 10 분 간격으로 각 3회 동안 연속적으로 실시하여, 백서가 escape platform 위로 도피하기까지 걸 리는 시간(초; second)과 거리(m)를 각각 측정하였다. 만약 백서가 180초 내에 escape platform을 찾지 못하면 도피 시간은 180초로 하였다.

\section{Infarct volume의 측정}

Lee 등 ${ }^{30)}$ 의 방법에 따라, 최종 희생일에 $70 \% \mathrm{~N}_{2} \mathrm{O}$ 와 $28.5 \% \mathrm{O}_{2}$ 가스에 $1.5 \%$ isoflurane을 혼합한 마취가스로 전 신마취를 시킨 후, 뇌조직을 적출한 다음 $4{ }^{\circ} \mathrm{C}$ 정도의 phosphate buffered saline (PBS, pH 7.4)로 냉각시키고, brain stainless steel coronal matrix (Harvard, MA, USA)를 이 용하여, 후뇌에서 2 14 mm 부분의 대뇌를 $2 \mathrm{~mm}$ 두께로 연속 절편 6개를 준비하고(Fig. 2), 2\% 2, 3, 5-triphenyl tetrazolium chloride (Sigma, MO, USA) 용액으로 $37^{\circ} \mathrm{C}$ 에서 $30 \mathrm{~min}$ 간 5 개의 뇌조직 절편을 염색한 다음, $10 \%$ neutral buffered formalin (NBF)에 overnight 고정시켰 다. 이후 $0.5 \mathrm{~mm}$ 간격의 grid 위에 놓은 다음 digital camera (Fujifilm, Tokyo, Japan) 영상을 촬영하여, 대뇌에서 관 찰되는 infarct 부위의 면적을 하기의 공식 [2]으로 자동영 상분석장치(iSolution FL ver 9.1, IMT i-solution Inc., Canada)를 이용하여 산출하였다. 


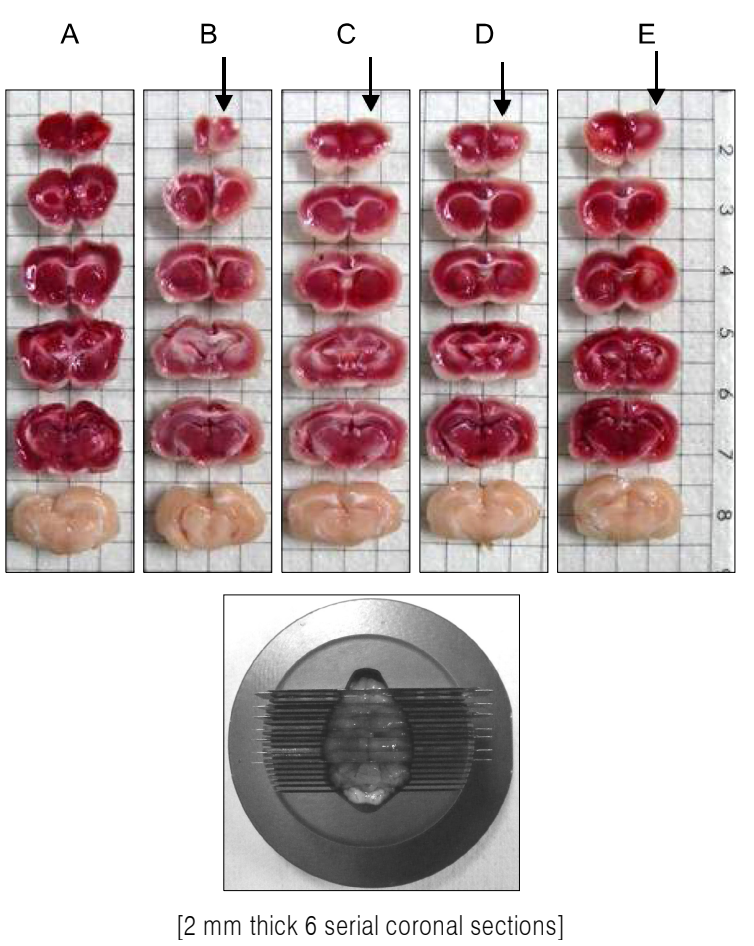

Fig. 2. Representative TTC-stained brain sections taken from sham-operated, tMCAO rats at 10 days postsurgery. Note that marked increases of focal cerebral infarct volumes were observed as compared with sham control rats in tMCAO control rats. However, marked decreases of cerebral infarct regions were demonstrated in all three different dosages of Joojakwhan treated rats as compared with tMCAO control rats, respectively. Last 6 th coronal sections were used for histolopathological and immunohistochemical analysis.

(A) Sham control, (B) tMCAO control, (C) Joojakwhan $125 \mathrm{mg} / \mathrm{kg}$ treated rats, (D) Joojakwhan $250 \mathrm{mg} / \mathrm{kg}$ treated rats, (E) Joojakwhan 500 $\mathrm{mg} / \mathrm{kg}$ treated rats.

Values are expressed as Mean $\pm S D$ of eight rat brain serial sections Arrows indicated infarct induced sides.

tMCAO: 60 min reperfusion transient Middle Cerebral Artery Occlusion, TTC: 3 , 5-Triphenyl Tetrazolium Chloride, SD: Standard deviation, MW test: Mann-Whitney $\mathrm{U}$ test.

EQUATION [2]. Infarct volumes

$=$ Sinfarct region area of six cerebral slices $\times 2 \mathrm{~mm}$ (thicknesses)

\section{9. 조직병리학적 관찰}

Brain stainless steel coronal matrix로 준비한 마지막 6번째 뇌조직 절편(Fig. 2)을 10\% 중성포르말린에 overnight 고정시킨 후, 탈수를 거쳐 파라핀 포매 후 $3 \mu \mathrm{m}$ 의 절편을 제작하였다. 이후 Hematoxylin \& eosin (H\&E) 염 색을 실시하고, 광학현미경 하에서 관찰하였다. 좀 더 명확 한 조직병리학적 변화를 관찰하기 위해, infarct 주변부 대
뇌피질의 위축 \%를 하기의 공식 [3]을 이용하여 계산하였으 며 ${ }^{30)}$, 단위 면적 $\left(\mathrm{mm}^{2}\right)$ 당 대뇌피질 변성 신경원의 수 역시 자동영상분석장치를 이용하여 산출하였다.

EQUATION [3]. Cerebral Atrophy Formation = (Contralateral cerebral cortex area-ipsilateral cerebral cortex area)/Contralateral cerebral cortex area $\times 100(\%)$

\section{0. 면역조직화학적 관찰}

준비한 파라핀 포매 뇌 조직 절편을 이용하여, AvidineBiotin-Peroxidase Complex (ABC) 방법 ${ }^{31)}$ 으로, caspase-3 및 PARP 면역반응성 신경원을 관찰하였다. 즉, citrate buffer antigen (epitope) retrieval pretreatment를 Shi 등 ${ }^{32)}$ 의 방법에 준하여 실시한 다음, $0.1 \% \mathrm{H}_{2} \mathrm{O}_{2}$ 가 포함된 methanol에 30분간 반응시켜 비특이적 peroxidase 반응을 차단 하고, normal goat serum에 1 시간 동안 반응시켜 내인성 peroxidase를 제거하였다. 이후 caspase-3 (Anti-cleaved caspase-3 (Asp175) polyclonal antibody; Cell Signaling Technology Inc, Beverly, MA, USA; Dilution, $1:$ 400) 吕 PARP (Anti-cleaved PARP (Asp214) rat specific antibody; Cell Signaling Technology Inc, Beverly, MA, USA; Dilution, $1: 100$ ) 일차항체에 $4^{\circ} \mathrm{C}$ 에 18 시간 이상 반응시 키고, biotinylated universal secondary antibody (Vector Lab. Inc., CA, USA. Dilution $1: 50$ )에 1시간 상온에서 반 응시킨 다음, avidin-biotin complex reagents (Vectastain Elite ABC Kit, Vector Lab. Inc., CA, USA. Dilution 1 : 50)에 1시간 상온에서 반응시키고, peroxidase substrate kit (Vector Lab. Inc., CA, USA)를 이용하여 발색시켰다. 발색 이후 Mayer's Hematoxylin으로 대조염색을 실시하 고, 광학현미경하에서 관찰하였다. 본 실험에서 $10 \%$ 이상의 발색반응을 나타내는 세포를 양성 면역반응세포로 간주하 고, 단위 면적 $\left(\mathrm{mm}^{2}\right)$ 당 대뇌피질내 caspase-3 및 PARP 양 성 면역반응 신경원의 수를 각각 자동영상분석장치를 이용 하여 산출하였다.

\section{1. 통계처리}

모든 수치는 평균표준편차로 표시하였으며, 다중비교 검증을 이용하여 통계처리를 실시하였고, 분산동질성을 Levene test를 실시하여 검증하였다. 등분산일 경우, one 
way ANOVA test를 실시한 다음 least-significant differences (LSD) test로 사후 검증을 실시하여 군 간의 유의성을 측정하였다. 비등분산일 경우에는 비모수 검증인 KruskalWallis $\mathrm{H}$ test를 실시한 후 유의성이 인정된 경우에는 Mann-Whitney U (MW) test를 실시하여 군 간의 유의성을 검증하였으며, Bonferroni correction을 시행하였다. 모든

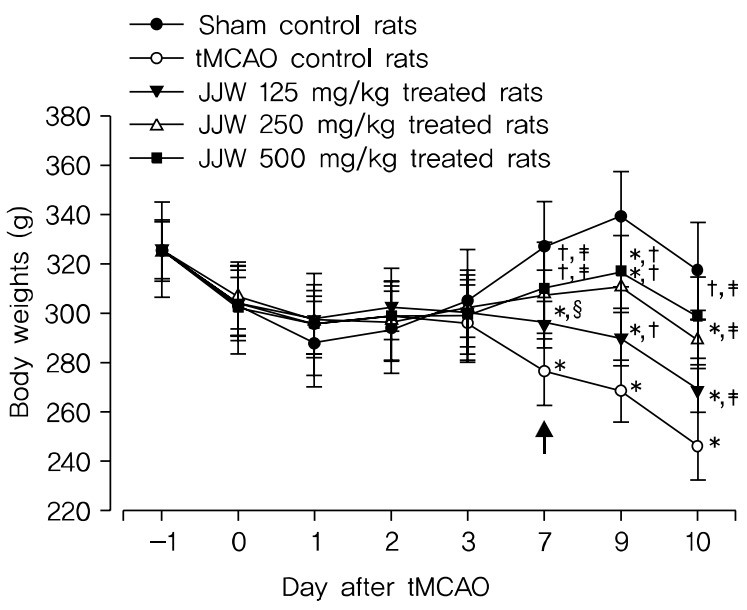

Fig. 3. Body weight changes in $\mathrm{MCAO}$ rats. Significant decreases of body weight were detected from 7 days after surgery in tMCAO control rats as compared with sham control rats (arrow). However, significant and dosage-dependent increases of body weights were observed from 7 days after tMCAO of JJW 125, 250 and $500 \mathrm{mg} / \mathrm{kg}$ treated rats as compared with $\mathrm{M} \mathrm{MCAO}$ control rats (arrow), respectively.

Values are expressed as Mean $\pm S D$ of eight rats.

-1 means, 1 day before $\mathrm{M} M \mathrm{CAO}$ surgery.

0 means at $\mathrm{MCAO}$ surgery.

All animals were overnight fasted before IMCAO and sacrifice (at 10 days after operation).

${ }^{*} p<0.01$ and ${ }^{\dagger} p<0.05$ as compared with sham control by LSD test. ${ }^{\dagger} p<0.01$ and ${ }^{\S} p<0.05$ as compared with $\mathrm{MMCAO}$ control by LSD test.

tMCAO: 60 min reperfusion transient Middle Cerebral Artery Occlusion, JJW: Joojakwhan grinded powders, SD: Standard deviation, LSD test: Least-Significant Differences test.
통계처리는 SPSS for Windows (Release 14.0K, SPSS Inc., Armonk, NY, USA) ${ }^{33)}$ 를 이용하여 평가하였으며, $\mathrm{p}^{-}$ value가 0.05 이하인 경우 통계적 유의성을 인정하였고, $\mathrm{tMCAO}$ 에 대한 주작환(朱雀丸)의 뇌보호 효과, 신경운동학 적 및 인지행동 장애 회복 효과를 좀 더 명확히 하기 위하여, 주작환(朱雀丸) 투여군과 $\mathrm{tMCAO}$ 대조군과의 percent change 를 하기의 공식 [4]를 이용하여 각각 측정하였다.

EQUATION [4]. Percentage Changes as Compared tMCAO Control (\%)

$=($ Data of JJW administered groups-Data of tMCAO control)/Data of tMCAO control) $\times 100$

\section{III. 결과}

\section{1. 체중의 변화}

$\mathrm{tMCAO}$ 대조군에서는 sham 대조군에 비해 유의성 있는 $(\mathrm{p}<0.01)$ 체중의 감소가 $\mathrm{tMCAO} 7$ 일 후부터 나타나기 시 작하여, 실험기간 동안의 증체량 역시 유의성 있는 $(\mathrm{p}<0.01)$ 감소를 나타내었다. 한편 $\mathrm{tMCAO}$ 대조군에 비해 유의성 있 는 $(p<0.01$ 또는 $p<0.05)$ 체중의 증가가 주작환(朱雀丸) 125, 250 및 $500 \mathrm{mg} / \mathrm{kg}$ 투여군에서 tMCAO 7일 후부터 실험 전기간 걸쳐 나타나, $\mathrm{tMCAO}$ 대조군에 비해 유의성 있는 $(\mathrm{p}<0.01)$ 체중의 증가를 각각 나타내었다(Fig. 3).

$\mathrm{tMCAO}$ 후 10 일 동안의 증체량은 주작환(朱雀丸) 125 , 250 및 $500 \mathrm{mg} / \mathrm{kg}$ 투여군에서 $\mathrm{tMCAO}$ 대조군에 비해 각 각 37.30, 70.32 및 93.65\%의 변화를 나타내었다.

Table 3. Forelimb Placing Scores Detected in IMCAO Rats

\begin{tabular}{|c|c|c|c|c|c|}
\hline \multirow{2}{*}{ Groups } & \multicolumn{5}{|c|}{ Days after tMCAO } \\
\hline & -1 & 1 & 3 & 7 & 10 \\
\hline \multicolumn{6}{|l|}{ Controls } \\
\hline Sham & $0.38 \pm 0.52$ & $0.50 \pm 0.53$ & $0.38 \pm 0.52$ & $0.25 \pm 0.46$ & $0.38 \pm 0.52$ \\
\hline tMCAO & $0.38 \pm 0.52$ & $9.38 \pm 1.41 *$ & $7.50 \pm 1.31^{*}$ & $6.50 \pm 1.41^{\ddagger}$ & $5.70 \pm 1.16^{*}$ \\
\hline \multicolumn{6}{|l|}{ Joojakwhan } \\
\hline $125 \mathrm{mg} / \mathrm{kg}$ & $0.50 \pm 0.53$ & $9.50 \pm 1.20$ * & $6.75 \pm 1.39 *$ & $4.75 \pm 1.28^{\ddagger}$ & $3.13 \pm 0.64^{*, \dagger}$ \\
\hline $250 \mathrm{mg} / \mathrm{kg}$ & $0.25 \pm 0.46$ & $9.38 \pm 1.30^{*}$ & $7.13 \pm 1.13^{*}$ & $4.00 \pm 0.53^{\neq, \S}$ & $2.88 \pm 0.83^{*} \dagger$ \\
\hline $500 \mathrm{mg} / \mathrm{kg}$ & $0.38 \pm 0.52$ & $9.50 \pm 1.07^{*}$ & $7.13 \pm 1.13^{*}$ & $3.63 \pm 1.06^{\neq . \S}$ & $2.38 \pm 0.74^{*} \dagger$ \\
\hline
\end{tabular}

Values are expressed as Mean $\pm S D$ of eight rats, scores $(M a x=12)$.

${ }^{*} p<0.01$ as compared with sham control by LSD test. ${ }^{+} p<0.01$ as compared with $\mathrm{MMCAO}$ control by LSD test. ${ }^{\dagger} p<0.05$ as compared with sham control by MW test. ${ }_{\mathrm{p}} \mathrm{p}<0.05$ as compared with $\mathrm{MCAO}$ control by MW test.

tMCAO: 60 min reperfusion transient Middle Cerebral Artery Occlusion, SD: Standard deviation, LSD test: Least-Significant Differences test, MW test: Mann-Whitney U test. 


\section{Forelimb placing test}

$\mathrm{tMCAO}$ 수술 24시간 후 신경학적 운동행동 검사 점수가 유사한 실험동물을 선정하여 사용하였으므로, $\mathrm{tMCAO}$ 대조 군에서는 sham 대조군에 비해 유의성 있는 $(\mathrm{p}<0.01)$ forelimb placing test 점수의 증가가 $\mathrm{tMCAO} 24$ 시간 후부터 실험 전 기간에 걸쳐 나타났다. 한편 세 용량의 모든 주작환 (朱雀丸) 투여군에서는 각각 $\mathrm{tMCAO} 7$ 및 10 일에 $\mathrm{tMCAO}$ 대조군에 비해 유의성 있는 $(p<0.01$ 또는 $p<0.05)$ forelimb placing test 점수의 감소가 나타났다(Table 3).

주작환(朱雀丸) $125 \mathrm{mg} / \mathrm{kg}$ 투여군에서는 $\mathrm{tMCAO}$ 대조군 에 비해 forelimb placing test 점수가 tMCAO 3, 7 및 10일 후 각각 $-10.00,-26.92$ 및 $-45.65 \%$ 의 변화를 나타내었다. 주작환(朱雀丸) $250 \mathrm{mg} / \mathrm{kg}$ 투여군에서는 $\mathrm{tMCAO}$ 대조군에 비해 forelimb placing test 점수가 tMCAO 3, 7 및 10일 후 각각 $-5.00,-38.46$ 및 $-50.00 \%$ 의 변화를 나타내었다. 주작환(朱雀丸) $500 \mathrm{mg} / \mathrm{kg}$ 투여군에서는 $\mathrm{tMCAO}$ 대조군에 비해 forelimb placing test 점수가 tMCAO 3, 7 및 10일 후 각각 $-5.00,-44.23$ 및 $-58.70 \%$ 의 변화를 나타내었다.

\section{Hindlimb placing test}

$\mathrm{tMCAO}$ 대조군에서는 sham 대조군에 비해 유의성 있는 $(\mathrm{p}<0.01)$ hindlimb placing test 점수의 증가가 $\mathrm{tMCAO}$ 24 시간 후부터 실험 전 기간에 걸쳐 나타났다. 한편 주작환 (朱雀丸) 125,250 및 $500 \mathrm{mg} / \mathrm{kg}$ 투여군에서는 $\mathrm{tMCAO}$ 대조군에 비해 유의성 있는(p<0.01) hindlimb placing test 점수의 감소가 $\mathrm{tMCAO} 7$ 및 10일 후에 나타났다(Table
4).

주작환(朱雀丸) $125 \mathrm{mg} / \mathrm{kg}$ 투여군에서는 $\mathrm{tMCAO}$ 대조 군에 비해 hindlimb placing test 점수가 $\mathrm{tMCAO} 3,7$ 및 10 일 후 각각 $-6.67,-34.62$ 및 $-43.48 \%$ 의 변화를 나타내 었다. 주작환(朱雀丸) $250 \mathrm{mg} / \mathrm{kg}$ 투여군에서는 $\mathrm{tMCAO}$ 대 조군에 비해 hindlimb placing test 점수가 $\mathrm{tMCAO} 3,7$ 및 10 일 후 각각 $-10.00,-38.46$ 및 $-47.83 \%$ 의 변화를 나 타내었다. 주작환(朱雀丸) $250 \mathrm{mg} / \mathrm{kg}$ 투여군에서는 $\mathrm{tMCAO}$ 대조군에 비해 hindlimb placing test 점수가 $\mathrm{tMCAO} 3$, 7 및 10 일 후 각각 $-13.33,-42.31$ 및 $-60.87 \%$ 의 변화를 나타내었다.

\section{Body swing test}

tMCAO 대조군에서는 sham 대조군에 비해 유의성 있는 $(\mathrm{p}<0.01)$ 우측으로의 body swing 횟수 및 비율의 감소가 $\mathrm{tMCAO} 24$ 시간 후부터 실험 전 기간에 걸쳐 나타났다. 한편 주작환(朱雀丸) 125,250 및 $500 \mathrm{mg} / \mathrm{kg}$ 투여군에서는 $\mathrm{tMCAO}$ 대조군에 비해 유의성 있는 $(\mathrm{p}<0.01)$ 우측으로의 body swing 횟수 및 비율의 증가가 투여 용량 의존적으로 $\mathrm{tMCAO}$ 3일 후부터 실험 전 기간에 걸쳐 각각 나타났다 (Table 5).

주작환(朱雀丸) $125 \mathrm{mg} / \mathrm{kg}$ 투여군에서는 $\mathrm{tMCAO}$ 대조 군에 비해 우측으로의 body swing 횟수 및 비율이 tMCAO 3,7 및 10 일 후 각각 $33.33,37.78$ 및 42.00\%의 변화를 나타내었다. 주작환(朱雀丸) $250 \mathrm{mg} / \mathrm{kg}$ 투여군에서는 $\mathrm{tMCAO}$ 대조군에 비해 우측으로의 body swing 횟수 및 비 율이 $\mathrm{tMCAO}$ 3, 7 및 10일 후 각각 52.78, 53.33 및

Table 4. Hindlimb Placing Scores Detected in IMCAO Rats

\begin{tabular}{|c|c|c|c|c|c|}
\hline \multirow{2}{*}{ Groups } & \multicolumn{5}{|c|}{ Days after tMCAO } \\
\hline & -1 & 1 & 3 & 7 & 10 \\
\hline \multicolumn{6}{|l|}{ Controls } \\
\hline Sham & $0.38 \pm 0.52$ & $0.25 \pm 0.46$ & $0.50 \pm 0.53$ & $0.38 \pm 0.52$ & $0.38 \pm 0.52$ \\
\hline tMCAO & $0.38 \pm 0.52$ & $4.00 \pm 0.53^{*}$ & $3.75 \pm 0.46^{*}$ & $3.25 \pm 0.46^{*}$ & $2.88 \pm 0.35^{\ddagger}$ \\
\hline \multicolumn{6}{|l|}{ Joojakwhan } \\
\hline $125 \mathrm{mg} / \mathrm{kg}$ & $0.50 \pm 0.53$ & $4.00 \pm 0.76^{*}$ & $3.50 \pm 0.76^{*}$ & $2.13 \pm 0.64^{*}+$ & $1.63 \pm 0.52^{\neq .8}$ \\
\hline $250 \mathrm{mg} / \mathrm{kg}$ & $0.13 \pm 0.35$ & $4.13 \pm 0.83^{*}$ & $3.38 \pm 0.74^{*}$ & $2.00 \pm 0.76^{*} \dagger$ & $1.50 \pm 0.53^{\neq .8}$ \\
\hline $500 \mathrm{mg} / \mathrm{kg}$ & $0.38 \pm 0.52$ & $4.00 \pm 0.76^{*}$ & $3.25 \pm 0.46^{*}$ & $1.88 \pm 0.64^{*} \dagger$ & $1.13 \pm 0.35^{\S}$ \\
\hline
\end{tabular}

Values are expressed as Mean \pm SD of eight rats, scores (Max $=6$ ).

${ }^{*} p<0.01$ as compared with sham control by LSD test. ${ }^{+} p<0.01$ as compared with $\mathrm{MMCAO}$ control by LSD test. ${ }^{\dagger} \mathrm{p}<0.05$ as compared with sham control by MW test. ${ }_{\mathrm{p}}<0.05$ as compared with tMCAO control by MW test. 
Table 5. Body Swing Scores Detected in tMCAO Rats

\begin{tabular}{|c|c|c|c|c|c|}
\hline \multirow{2}{*}{ Groups } & \multicolumn{5}{|c|}{ Days after tMCAO } \\
\hline & -1 & 1 & 3 & 7 & 10 \\
\hline \multicolumn{6}{|c|}{ [Unit: the numbers of body swings to the ipsilateral right sides/total 30 body swings] } \\
\hline \multicolumn{6}{|c|}{ Controls } \\
\hline Sham & $12.25 \pm 1.75$ & $15.13 \pm 1.64$ & $14.75 \pm 1.39$ & $14.75 \pm 1.28$ & $14.88 \pm 1.36$ \\
\hline tMCAO & $15.38 \pm 0.92$ & $3.50 \pm 1.07^{\S}$ & $4.50 \pm 0.93^{*}$ & $5.63 \pm 0.74^{*}$ & $6.25 \pm 1.04^{*}$ \\
\hline \multicolumn{6}{|l|}{ Joojakwhan } \\
\hline $125 \mathrm{mg} / \mathrm{kg}$ & $15.13 \pm 1.36$ & $3.25 \pm 0.71^{\S}$ & $6.00 \pm 1.51^{*} \neq$ & $7.75 \pm 1.58^{*} \dagger$ & $8.88 \pm 1.64^{*}+$ \\
\hline $250 \mathrm{mg} / \mathrm{kg}$ & $15.38 \pm 1.19$ & $3.38 \pm 0.92^{\S}$ & $6.88 \pm 1.55^{\star}+\dagger$ & $8.63 \pm 1.51^{*} \dagger$ & $10.75 \pm 1.67^{*}+\dagger$ \\
\hline $500 \mathrm{mg} / \mathrm{kg}$ & $15.13 \pm 0.83$ & $3.50 \pm 0.93^{\S}$ & $7.25 \pm 1.28^{*}+\dagger$ & $8.88 \pm 1.25^{\star}+\dagger$ & $11.38 \pm 1.06^{*}+\dagger$ \\
\hline \multicolumn{6}{|c|}{ [Unit: the percentages of body swings to the ipsilateral right sides/total 30 body swings] } \\
\hline \multicolumn{6}{|c|}{ Controls } \\
\hline Sham & $50.83 \pm 5.84$ & $50.42 \pm 5.47$ & $49.17 \pm 4.63$ & $49.17 \pm 4.27$ & $49.58 \pm 4.52$ \\
\hline tMCAO & $51.25 \pm 3.05$ & $11.67 \pm 3.56^{\S}$ & $15.00 \pm 3.09 *$ & $18.75 \pm 2.48 *$ & $20.83 \pm 3.45^{*}$ \\
\hline \multicolumn{6}{|l|}{ Joojakwhan } \\
\hline $125 \mathrm{mg} / \mathrm{kg}$ & $50.42 \pm 4.52$ & $10.83 \pm 2.36^{\S}$ & $20.00 \pm 5.04^{* \neq}$ & $25.83 \pm 5.27^{*}+\dagger$ & $29.58 \pm 5.47^{*}+$ \\
\hline $250 \mathrm{mg} / \mathrm{kg}$ & $51.25 \pm 3.98$ & $11.25 \pm 3.05^{\S}$ & $22.92 \pm 5.18^{* \dagger}$ & $28.75 \pm 5.02^{*}{ }^{\dagger}$ & $35.83 \pm 5.56^{*}, \dagger$ \\
\hline $500 \mathrm{mg} / \mathrm{kg}$ & $50.42 \pm 2.78$ & $11.67 \pm 3.09^{\S}$ & $24.17 \pm 4.27^{*}+\dagger$ & $29.58 \pm 4.15^{* \dagger}$ & $37.92 \pm 3.54^{*}+\dagger$ \\
\hline
\end{tabular}

Values are expressed as Mean \pm SD of eight rats.

${ }^{\star} p<0.01$ as compared with sham control by LSD test. ${ }^{\dagger} p<0.01$ and ${ }^{\dagger} p<0.05$ as compared with $\mathrm{MCAO}$ control by LSD test. ${ }^{\S} \mathrm{p}<0.05$ as compared with sham control by MW test.

tMCAO: 60 min reperfusion transient Middle Cerebral Artery Occlusion, SD: Standard deviation, LSD test: Least-Significant Differences test, MW test: Mann-Whitney U test.

Table 6. Cognitive Behavioral Scores Detected in Water Maze Test of tMCAO Rats

\begin{tabular}{|c|c|c|c|c|}
\hline \multirow{3}{*}{ Groups } & \multicolumn{4}{|c|}{ At 10 days after tMCAO } \\
\hline & \multicolumn{3}{|c|}{ Trials } & \multirow{2}{*}{ Mean } \\
\hline & 1 & 2 & 3 & \\
\hline \multicolumn{5}{|c|}{ The distance to reach the escape platform (m) } \\
\hline \multicolumn{5}{|c|}{ Controls } \\
\hline Sham & $18.21 \pm 0.92$ & $10.31 \pm 1.76$ & $7.10 \pm 1.58$ & $11.87 \pm 1.26$ \\
\hline tMCAO & $18.94 \pm 1.46$ & $17.73 \pm 1.50^{\star}$ & $15.29 \pm 1.82 *$ & $17.32 \pm 1.16^{*}$ \\
\hline \multicolumn{5}{|l|}{ Joojakwhan } \\
\hline $125 \mathrm{mg} / \mathrm{kg}$ & $19.07 \pm 1.49$ & $15.48 \pm 1.65^{\star, \neq}$ & $12.72 \pm 1.10^{*}, \neq$ & $15.76 \pm 1.24^{*, \neq}$ \\
\hline $250 \mathrm{mg} / \mathrm{kg}$ & $18.94 \pm 1.16$ & $14.20 \pm 1.21^{*}, \neq$ & $10.90 \pm 1.17^{\star}, \neq$ & $14.68 \pm 0.85^{\star, \neq}$ \\
\hline $500 \mathrm{mg} / \mathrm{kg}$ & $18.96 \pm 1.25$ & $14.05 \pm 1.42^{*}, \neq$ & $9.57 \pm 1.00^{\star \neq}$ & $14.19 \pm 0.95^{\star \neq} \neq$ \\
\hline \multicolumn{5}{|c|}{ The time to reach the escape platform (sec) } \\
\hline \multicolumn{5}{|c|}{ Controls } \\
\hline Sham & $106.75 \pm 18.09$ & $82.88 \pm 16.72$ & $49.00 \pm 11.75$ & $79.54 \pm 13.92$ \\
\hline tMCAO & $144.25 \pm 15.41^{\S}$ & $136.25 \pm 12.30^{*}$ & $122.63 \pm 9.36^{*}$ & $134.38 \pm 11.63^{*}$ \\
\hline \multicolumn{5}{|l|}{ Joojakwhan } \\
\hline $125 \mathrm{mg} / \mathrm{kg}$ & $127.88 \pm 6.60$ & $98.75 \pm 12.52^{\dagger, \ddagger}$ & $77.63 \pm 14.49^{*}, \neq$ & $101.42 \pm 10.06^{*} \neq$ \\
\hline $250 \mathrm{mg} / \mathrm{kg}$ & $125.63 \pm 5.32^{\|}$ & $92.38 \pm 15.67^{\ddagger}$ & $69.25 \pm 10.75^{\star *}$ & $95.75 \pm 8.63^{*}$ \\
\hline $500 \mathrm{mg} / \mathrm{kg}$ & $117.75 \pm 6.65^{\|}$ & $88.75 \pm 9.25^{\ddagger}$ & $64.38 \pm 11.27^{\dagger, \ddagger}$ & $90.29 \pm 7.22^{\dagger, \neq}$ \\
\hline
\end{tabular}

Values are expressed as Mean \pm SD of eight rats

${ }^{*} p<0.01$ and ${ }^{\dagger} p<0.05$ as compared with sham control by LSD test. ${ }^{\dagger} p<0.01$ as compared with tMCAO control by LSD test. ${ }^{\S} p<0.05$ as compared with sham control by MW test. " $p<0.05$ as compared with $\mathrm{MCAO}$ control by MW test.

tMCAO: 60 min reperfusion transient Middle Cerebral Artery Occlusion, SD: Standard deviation, LSD test: Least-Significant Differences test, MW test: Mann-Whitney U test. 
$72.00 \%$ 의 변화를 나타내었다. 주작환(朱雀丸) $500 \mathrm{mg} / \mathrm{kg}$ 투여군에서는 $\mathrm{tMCAO}$ 대조군에 비해 우측으로의 body swing 횟수 및 비율이 tMCAO 3, 7 및 10일 후 각각 61.11, 57.78 및 $82.00 \%$ 의 변화를 나타내었다.

\section{Water maze test}

Sham 대조군에서는 water maze tank내에서 escape platform까지의 이동거리 및 시간이 trial을 반복할 때 마다 현저히 감소되었으나, $\mathrm{tMCAO}$ 대조군에서는 sham 대조군 에 비해 유의성 있는 $(p<0.01)$ escape platform까지 움직 인 거리 및 시간의 증가가 $\mathrm{tMCAO} 10$ 일후 나타났으며, trial 횟수에 따른 이동거리 및 시간의 단축 역시 현저히 억제되 었다. 한편 모든 세 용량의 주작환(朱雀丸) 투여군에서는 $\mathrm{tMCAO}$ 대조군에 비해 유의성 있는(p<0.01 또는 $\mathrm{p}<0.05)$ escape platform까지의 이동거리 감소가 tMCAO 10일 후 trial 2 및 3에서 각각 나타났으며, escape platform까지의 이동시간의 유의성 있는 $(\mathrm{p}<0.01)$ 감소 역시 모든 trials에 서 투여 용량 의존적으로 각각 나타났다(Table 6).

주작환(朱雀丸) $125 \mathrm{mg} / \mathrm{kg}$ 투여군에서는 $\mathrm{tMCAO}$ 대조 군에 비해 water maze tank내에서 escape platform까지 의 이동거리가 $\mathrm{tMCAO} 10$ 일 후 trial 1, 2 및 3에 각각 0.68 , -12.68 및 $-16.82 \%$ 의 변화를 나타내었고, escape platform까지의 이동시간이 각각 $-11.35,-27.52$ 및 $-36.70 \%$ 의 변화를 나타내었다.

주작환(朱雀丸) $250 \mathrm{mg} / \mathrm{kg}$ 투여군에서는 $\mathrm{tMCAO}$ 대조 군에 비해 water maze tank내에서 escape platform까지 의 이동거리가 $\mathrm{tMCAO} 10$ 일 후 trial 1,2 및 3 에 각각 $-0.02,-19.89$ 및 $-28.71 \%$ 의 변화를 나타내었고, escape platform까지의 이동시간이 각각 $-12.91,-32.20$ 및 $-43.53 \%$ 의 변화를 나타내었다.

주작환(朱雀丸) $500 \mathrm{mg} / \mathrm{kg}$ 투여군에서는 $\mathrm{tMCAO}$ 대조 군에 비해 water maze tank내에서 escape platform까지 의 이동거리가 $\mathrm{tMCAO} 10$ 일 후 trial 1, 2 및 3에 각각 0.11, -20.78 및 $-37.38 \%$ 의 변화를 나타내었고, escape platform까지의 이동시간이 각각 $-18.37,-34.86$ 및 $-47.50 \%$ 의 변화를 나타내었다.

\section{Infarct volume}

$\mathrm{tMCAO} 10$ 일 후 최종 부검시, $\mathrm{tMCAO}$ 대조군에서는 대 뇌피질에서 현저한 infarct 소견이 나타났으며, sham 대조 군에 비해 유의성 있는(p<0.05) infarct volume의 증가가 나타났다. 한편 주작환(朱雀丸) 125,250 및 $500 \mathrm{mg} / \mathrm{kg}$ 투 여군에서는 $\mathrm{tMCAO}$ 대조군에 비해 유의성 있는( $\mathrm{p}<0.05)$ infarct volume의 감소가 투여 용량 의존적으로 각각 나타 났다(Fig. 2 and 4).

주작환(朱雀丸) 125,250 및 $500 \mathrm{mg} / \mathrm{kg}$ 투여군에서 $\mathrm{tMCAO}$ 대조군에 비해 각각 $-17.34,-22.50$ 및 $-30.74 \%$ 의 infarct volume의 변화가 나타났다.

\section{7. 조직병리학적 변화}

Infarct 주변부위의 조직병리학적 표본에서, $\mathrm{tMCAO}$ 대 조군에서는 유발부위인 우측 대뇌반구의 유의성 있는 $(\mathrm{p}<$ $0.05)$ 현저한 위축과 단위 면적당 $\left(\mathrm{mm}^{2}\right)$ 대뇌피질내 변성 신경원, caspase-3 및 PARP 면역 반응세포의 수적 증가가 나타났다. 한편 세 용량의 모든 주작환(朱雀丸) 투여군에서 는 $\mathrm{tMCAO}$ 대조군에 비해 유의성 있는 $(\mathrm{p}<0.01)$ 대뇌 피질

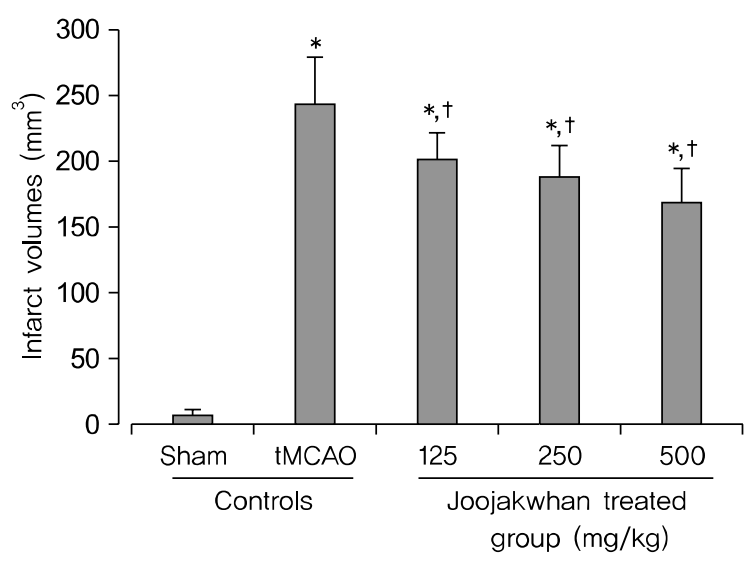

Fig. 4. Changes on the infarct volumes of sham-operated, tMCAO rats at 10 days postsurgery. Note that significant increases of focal cerebral infarct volumes were observed as compared with sham control rats in tMCAO control rats. And, significant and dosage-dependent decreases of infarct volumes were demonstrated in all three different dosages of Joojakwhan treated rats as compared with $\mathrm{MCAO}$ control rats, respectively.

Values are expressed as Mean $\pm S D$ of eight rat brain serial sections.

${ }^{\star} p<0.05$ as compared with sham control by MW test. ${ }^{\dagger} p<0.05$ as compared with $\mathrm{TMCAO}$ control by MW test.

tMCAO: 60 min reperfusion transient Middle Cerebral Artery Occlusion, MW test: Mann-Whitney U test. 
Table 7. Histomorphometry of Peri-infarct/defect Cerebral Cortex in tMCAO Rats

\begin{tabular}{|c|c|c|c|c|}
\hline \multirow{2}{*}{ Groups } & \multirow{2}{*}{ Cerebral atrophic \% } & \multicolumn{3}{|c|}{ Numbers of neurons (cells/mm ${ }^{2}$ of cerebral cortex) } \\
\hline & & Degenerative cells & Caspase-3 + & PARP + \\
\hline \multicolumn{5}{|l|}{ Controls } \\
\hline Sham & $2.90 \pm 1.74$ & $6.75 \pm 4.06$ & $6.88 \pm 2.53$ & $8.63 \pm 1.69$ \\
\hline tMCAO & $54.58 \pm 8.38 *$ & $79.25 \pm 11.54^{\ddagger}$ & $77.00 \pm 9.01^{\ddagger}$ & $78.13 \pm 11.15^{\ddagger}$ \\
\hline \multicolumn{5}{|l|}{ Joojakwhan } \\
\hline $125 \mathrm{mg} / \mathrm{kg}$ & $41.65 \pm 5.13^{*}+$ & $62.38 \pm 7.37^{\neq . \S}$ & $63.00 \pm 9.72^{\neq . \S}$ & $64.75 \pm 7.98^{\ddagger}$ \\
\hline $250 \mathrm{mg} / \mathrm{kg}$ & $38.14 \pm 5.01^{*}+\dagger$ & $49.50 \pm 5.71^{\mp, \S}$ & $48.50 \pm 6.65^{\neq, \S}$ & $52.50 \pm 7.19^{\neq . \S}$ \\
\hline $500 \mathrm{mg} / \mathrm{kg}$ & $29.88 \pm 5.83^{*} \dagger$ & $29.00 \pm 2.45^{\neq . \S}$ & $35.50 \pm 3.34^{\neq, \S}$ & $38.75 \pm 10.25^{\ddagger \S \S}$ \\
\hline
\end{tabular}

Values are expressed as Mean \pm SD of eight rat brain specimens.

${ }^{\star} p<0.01$ as compared with sham control by LSD test. ${ }^{\dagger} p<0.01$ as compared with $\mathrm{IMCAO}$ control by LSD test. ${ }^{\dagger} p<0.05$ as compared with sham control by MW test. ${ }^{s} \mathrm{p}<0.05$ as compared with tMCAO control by MW test.

tMCAO: 60 min reperfusion transient Middle Cerebral Artery Occlusion, PARP: Cleaved Poly (ADP-ribose) Polymerase, SD: Standard deviation, LSD test: Least-Significant Differences test, MW test: Mann-Whitney U test.

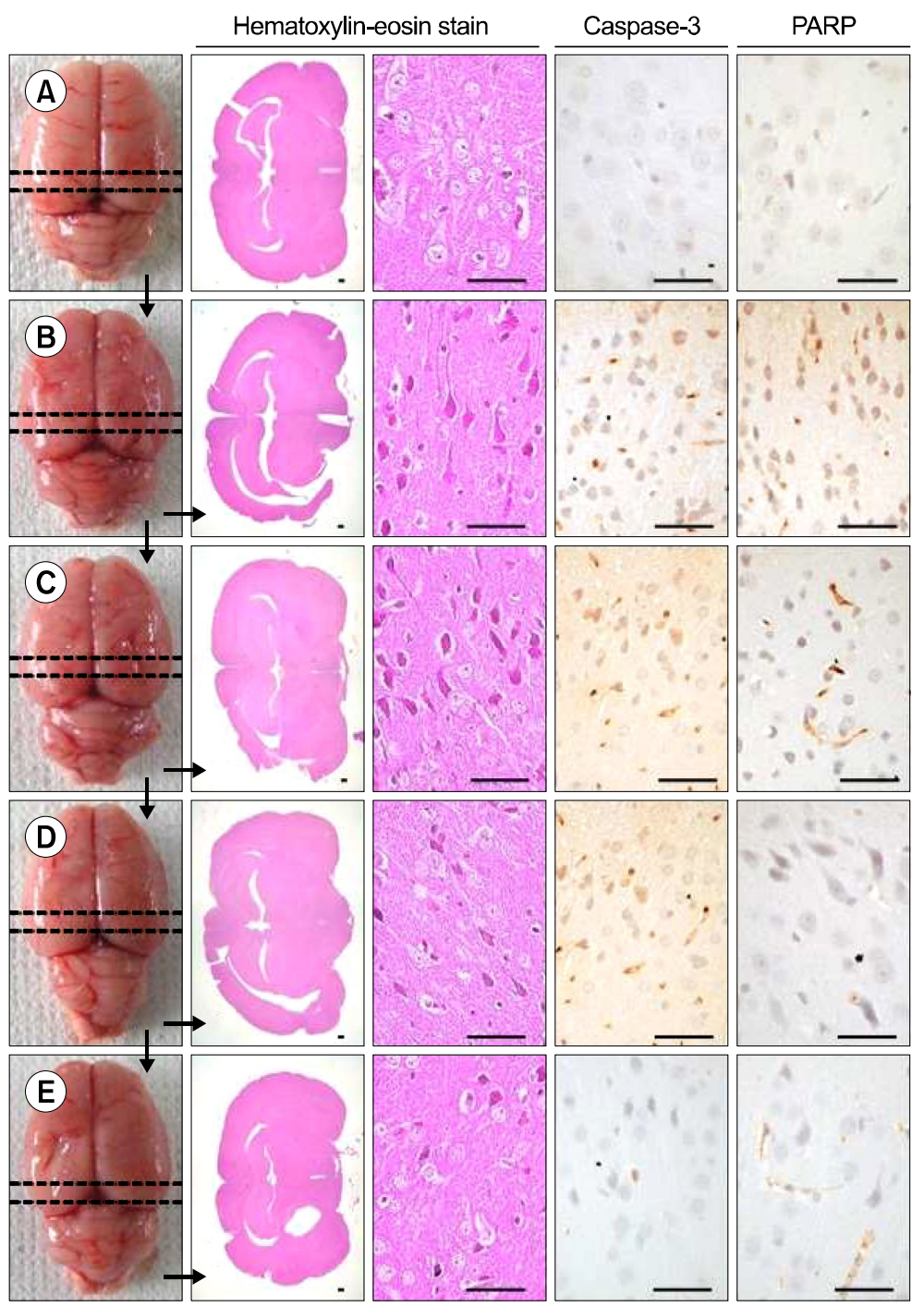

Fig. 5. Representative histological and caspase-3and PARP-immunoreactive neurons in the brain sections taken from sham-operated, tMCAO rats at 10 days postinjury. In tMCAO control rats, significant increases atrophic \% of ipsilateral cerebral cortex, the numbers of degenerative neurons, caspase-3and PARP-immunoreactive cells were observed as compared with sham control rats. In this experiment, Joojakwhan 125, 250 and $500 \mathrm{mg} / \mathrm{kg}$ markedly and dosage-dependently inhibited the IMCAO related cerebral atrophy and the increases of degenerative, caspase-3- and PARP-immunoreactive cells in the peri-infarct cerebral cortex as compared with IMCAO control rats, respectively. (A) Sham control, (B) tMCAO control, (C) Joojakwhan 125 $\mathrm{mg} / \mathrm{kg}$ treated rats, (D) Joojakwhan $250 \mathrm{mg} / \mathrm{kg}$ treated rats, (E) Joojakwhan $500 \mathrm{mg} / \mathrm{kg}$ treated rats. Arrows indicated proximal middle cerebral artery. Dot lines mean the area of histological preparations. tMCAO: $60 \mathrm{~min}$ reperfusion transient Middle Cerebral Artery Occlusion, PARP: Cleaved Poly (ADP-ribose) Polymerase, Scale bars $=100 \mu \mathrm{m}$. 
위축 억제가 나타났으며, 대뇌 피질내 변성 신경원, caspase-3 및 PARP 면역 반응세포의 수 역시 유의성 있는(p< $0.05)$ 감소를 투여 용량 의존적으로 각각 나타내었다(Table 7, Fig. 5).

주작환(朱雀丸) 125, 250 및 $500 \mathrm{mg} / \mathrm{kg}$ 투여군에서 유 발부위인 우측 대뇌반구의 위축정도가 $\mathrm{tMCAO}$ 대조군에 비 해 각각 $-23.69,-30.12$ 및 $-42.28 \%$ 의 변화를 나타내었다.

주작환(朱雀丸) 125,250 및 $500 \mathrm{mg} / \mathrm{kg}$ 투여군에서 유 발부위인 우측 대뇌피질에서 단위 면적당 변성 신경원의 수 가 $\mathrm{tMCAO}$ 대조군에 비해 각각 $-21.29,-37.54$ 및 $-63.41 \%$ 의 변화를 나타내었다.

주작환(朱雀丸) 125,250 및 $500 \mathrm{mg} / \mathrm{kg}$ 투여군에서 유 발부위인 우측 대뇌피질에서 단위 면적당 caspase-3 면역 반응 신경원의 수가 $\mathrm{tMCAO}$ 대조군에 비해 각각 -18.18 , -37.01 및 $-53.90 \%$ 의 변화를 나타내었다.

주작환(朱雀丸) 125,250 및 $500 \mathrm{mg} / \mathrm{kg}$ 투여군에서 유 발부위인 우측 대뇌피질에서 단위 면적당 PARP 면역반응 신경원의 수가 $\mathrm{tMCAO}$ 대조군에 비해 각각 - $17.12,-32.80$ 및 $-50.40 \%$ 의 변화를 나타내었다.

\section{IV. 고찰}

치매는 단기 기억과 다른 인지기능 결함 문제로 특징되어 지는 뇌의 기질적 퇴행을 말하며 ${ }^{34)}$, 초기에는 가벼운 건망증 정도로 시작하여 시간이 흐르면서 점차 증상이 악화되어 모 든 뇌기능을 상실하게 되는 임상증후군이다 ${ }^{35}$. 치매는 크게 뇌의 퇴행성 변화로 일어나는 알츠하이머 치매, 뇌의 동맥 경화나 뇌졸중의 후에 속발하는 혈관성 치매, 그 외의 원인 절환에 의한 속발성 치매 등으로 분류할 수 있다하. 이 중 알츠하이머로 인한 치매가 가장 큰 비중을 차지하고 혈관성 치매가 그 다음을 잇는 것으로 알려져 있으며, 국내의 경우에 도 전체 치매 환자 중 알츠하이머 치매가 $70.5 \%$, 혈관성 치매 가 $24.4 \%$ 로, 두 번째로 많은 것으로 추정되고 있다 $34,37,38)$.

알츠하이머 치매는 뇌의 퇴행성 변화에 의한 질환으로 $\beta$-amyloid, estrogen, apolipoprotein E, preseniline, oxidants (hydrogen, superoxide, hydroxyl radicals), 염 증, 신경전달물질 등의 다양한 유발인자가 관여하는 것으로 알려져 있다 ${ }^{39)}$.

이와는 달리 혈관성 치매는 일반적으로 뇌혈관 질환에
의해 야기되는 인지장애라 할 수 있다 ${ }^{40)}$. 혈관성 치매는 대 부분 뇌졸중 이후에 나타는데, 뇌졸중에 의한 허혈로 인해 야기되는 산소부족과 재관류시에 나타나는 활성산소에 의 한 허혈성 뇌신경세포의 손상은 혈관성치매의 원인으로 여 겨진다 ${ }^{4,5,12)}$. 혈관성 치매 초기에는 부분적인 지능 상실과 불면, 건망, 우울증, 기억력 저하 등이 나타나며 감정의 변화 가 커지는 경향이 있으나 판단력과 인격은 정상적으로 유지 되고 이후 질병의 진행에 따라 기억장애, 지남력상실, 언어 장애, 인지장애, 정서장애 등의 증상이 나타나게 된다 ${ }^{14}$.

한의학에서는 아직 서양의학과 같은 치매의 유형적 분류 가 이루어지지 않고 있으나 임상적으로 매병(呆病), 건망(健 忘), 전광(頯狂)의 범주로 보고 변증시치를 하고 있는데, 혈 관성 치매의 경우는 대부분 뇌졸중의 후속 질환으로 나타나 므로 한의학적 범주에서는 중풍(中風)에 해당한다고 볼 수 있으며 그 증상의 양상에 따라 치매(痴呆), 건망(健忘)의 범 주로 볼 수 있다 ${ }^{14)}$.

한의학에서 치매(痴呆)에 대한 최초의 언급은 명대 장개 빈(明代 張介賓)의 《경악전서(景岳全書)》 ${ }^{41}$ 에 “치애증은 평소엔 담이 없다가 울결이 생겼거나 풍을 맞았거나 생각을 많이 하였거나 의심이 생겼거나 놀랐거나 해서 점차 치애증 이 된다. 말이 뒤죽박죽이고 거동이 경우에 맞지 않으며 때 로는 땀을 많이 흘리거나 우수에 잠긴다. 그 증이 다양하고 기괴하여 이르지 않는 곳이 없다. 맥은반드시 현하거나 삭 하거나 대하거나 소하여 변화무상하다(痴業症 凡平素無痰 而或以厒結 或以不遂 或以思慮 或以疑惑 或以驚恐而 漸至 痴獃 言辭顛倒 擧動不經 或多汗 或善愁 其症則千奇萬怪 無 所不至, 脈必或弦或數, 或大或小, 變易不常) ...”라고 한 것에 서 볼 수 있으며, 이후 청대(清代)의 석실비록(石室秘錄) ${ }^{42}$,

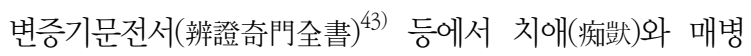
(呆病)의 병인병기(病因病機)와 증후(症候)에 관하여 설명하 고 있다.

중의학에서는 혈관성 치매를 선망(善忘), 치매(痴呆), 중 풍치매(中風痴朵) 등의 범주로 보고 있으며, 임상증상으로 는 건망(健忘), 반응지둔(反應遲鈍), 기억력감퇴(記憶力減 退), 계산능력저하(計算能力低下), 판단장애(判斷障碍), 대 소변실금(大小便失禁), 수족마목(手足瘷木), 반신불수(牛身 不遂) 등이 있다고 하였다. 그 병인병기(病因病機)는 대부분 본허표실(本虛表實), 허실협잡(虛實挾雜)으로 신정허손(腎 精虛損), 간양상항(肝陽上立)이 표(標)가 되고, 중풍(中風) 
이후에 뇌락(腦絡) 에 어조(瘀阻) 등이 생겨 뇌수(腦髓)가 손 상(損傷)되어 신(腎)의 정기 (精氣)가 뇌(腦)에 도달하지 못 하여 원신(元神)이 실양(失養)되어 본병(本病)이 된다고 보 아 치료에 있어 표본겸치(標本兼治)를 중요시하였다 ${ }^{44)}$.

본 연구에서 사용된 주작환(朱雀丸)은 《의학입문(醫學 入門)》 ${ }^{16}$ 에 수록된 처방으로 복신(获神) $80 \mathrm{~g}$, 침향(沈香) $20 \mathrm{~g}$ 을 가루 내어 팥알정도 크기로 빚은 후 30환을 식후에 인삼(人衤) 달인 물로 복용한다. 복신(获神)은 영심안신(寧 心安神), 이수(利水)의 효능이 있어 심허(心虛)로 인한 경계 건망(驚悸健忘)과 불면경간(不眠驚癎)을 치료하고, 침향(沈 香)은 경락(經絡)을 소통시켜 혈(血)이 기(氣)를 따라 행(行) 하게 하며 제기(諸氣)를 기르고 위기(衛氣)를 보(保)하며 진 기(眞氣)를 강(岡)하게하는 효능이 있다. 인삼(人蔘)은 대보 원기(大補元氣), 고탈생진(固脫生津), 안신익지(安神益智)의 효능이 있어 정신(精神)을 안정시키며 경계(驚悸)를 그치게 하고 사기(邪氣)를 제거하며 모든 기허증(氣虛證)에 양호한 효과를 나타내는 약재이다 ${ }^{45,46}$.

본 실험에서는 한의학(韓醫學)에서 신경안정제(神經安靜 劑) 및 치매 치료제(痴呆 治療劑)로 알려져 있는 주작환(朱 雀丸)의 허혈성 뇌손상에서 인지 및 운동기능 회복효과를 mild stroke 동물 모델인 $\mathrm{tMCAO}$ 백서 ${ }^{30,47,48)}$ 에서 평가하기 위해, 주작환(朱雀丸) 125,250 및 $500 \mathrm{mg} / \mathrm{kg}$ 을 $\mathrm{tMCAO}$ 유발 2시간 후부터 매일 10일간 경구투여하고, 체중, infarct volume, 신경학적 운동행동 및 인지적 운동행동 검사 의 변화를 관찰하였으며, infarct 주변부위의 대뇌 위축, 변 성 신경세포의 수, caspase-3 및 PARP 면역반응 신경세포 의 수적 변화를 조직병리학적 및 면역조직화학적 방법으로 각각 관찰하였다. 신경학적 운동행동 검사로 limb placing test $^{26)}$ 및 body swing test ${ }^{27}$ 를 $\mathrm{tMCAO}$ 1일전, tMCAO 1, 3,7 및 10 일 후에 각각 측정하였으며, 인지적 운동행동 검 사로, water maze test를 Moriss의 방법 ${ }^{28}$ 에 따라 $\mathrm{tMCAO}$ 10 일 후 측정하였다.

중대뇌동맥(middle cerebral artery)의 국소적인 폐쇄는 사람에서 가장 흔한 뇌졸중의 원인으로 알려져 있다 ${ }^{49)}$. Tamura 등 ${ }^{50)}$ 에 의해 처음 개발된 백서 $\mathrm{MCA}$ 폐쇄술 $(\mathrm{MCAO})$ 은 사람의 뇌졸중에서와 거의 유사한 병리 및 증상 을 나타내어 ${ }^{49,51)}$, 사람의 뇌졸중에 대한 병리와 증상을 연구 하는 대표적인 동물 모델로 알려져 있고 ${ }^{49)}$, 현재 뇌졸중 치 료제 개발에서 가장 일반적으로 이용되고 있다 ${ }^{52)}$. 백서에서
$\mathrm{MCAO}$ 에 대한 기본적인 병리생리학적 연구 역시 많이 수행 되어 있고, 기본 자료가 풍부하여 결과 판단에 매우 용이하 다 ${ }^{53,54)}$. 혈관내 필라멘트 (filament) 삽입을 이용한 일시적 인 국소 뇌허혈 동물 모델(transient $\mathrm{MCAO}, \mathrm{tMCAO})$ 은 Koizumi 등 ${ }^{55)}$ 에 의해 처음 개발된 동물 모델로, 외과적 필 요에 따라 필라멘트를 제거하여 재관류를 실시할 수 있어 ${ }^{29}$, 비교적 경미한 뇌졸중에 대한 동물 모델로 각광 받고 있 다 ${ }^{30,47,48)}$. 일반적으로 $\mathrm{tMCAO}$ 동물 모델에서의 약효 평가 는 경색부위(infarct volume), 운동신경(sensorimotor function) 및 인지 행동장애(cognitive motor behavior), 뇌부 종 또는 위축 정도, 대뇌 피질의 조직병리학적 변화를 기초 로 평가하고 있다 ${ }^{30,52)}$.

본 실험의 결과 이전의 연구들과 유사하게 ${ }^{30,47,48,52)}$, $\mathrm{tMCAO}$ 에 의한 현저한 체중 감소, 신경학적 및 인지적 운동 행동 장애소견, 즉 limb placing test score의 증가, 우측으 로의 body swing 횟수 및 비율의 감소, escape platform까 지의 이동거리 및 시간의 증가와 반복적 trial에 따른 이동거 리 및 시간의 단축의 억제가 나타났다. 또한 infarct 주변부 위의 조직병리학적 표본에서 유발 우측 대뇌반구의 위축, 대뇌 피질내 단위 면적당 변성 신경원, caspase-3 및 PARP 양성 신경원의 수적 증가가 초래되었다. 이러한 $\mathrm{tMCAO}$ 에 의한 체중 감소, 신경학적 및 인지적 운동행동 장애 및 infarct 주변부위 대뇌 피질 신경원의 변성 소견은 주작환 (朱 雀丸) 125,250 및 $500 \mathrm{mg} / \mathrm{kg}$ 투여에 의해 각각 현저히 억제되었다. 따라서 주작환(朱雀丸)이 stroke와 같은 허혈성 뇌손상에 따른 신경학적 및 인지적 운동행동 장애에 매우 유효한 효과를 나타내는 것으로 판단된다.

$\mathrm{tMCAO}$ 에 의한 허혈성 뇌손상이 진행됨에 따라 인지 및 운동장애가 초래되고, 결과적으로 현저한 체중 저하가 수반 된다 ${ }^{56-58)}$. 본 실험의 결과에서도 $\mathrm{tMCAO}$ 7일 후부터 sham 대조군에 비해 유의성 있는 $(\mathrm{p}<0.01)$ 체중의 감소가 모든 $\mathrm{tMCAO}$ 수술군에서 나타났으며, 실험기간 동안 증체량 역 시 sham 대조군에 비해 유의성 있는 $(\mathrm{p}<0.01)$ 감소를 나타 내었다. 그러나 모든 세 용량의 주작환(朱雀丸) 투여군에서 $\mathrm{tMCAO}$ 대조군에 비해 유의성 있는(p<0.01 또는 $\mathrm{p}<0.05)$ 체중의 증가가 $\mathrm{tMCAO}$ 7일 후부터 투여 용량 의존적으로 나타났다. 이러한 결과는 주작환(朱雀丸)이 $\mathrm{tMCAO}$ 에 의한 인지 및 행동장애에 의한 체중 감소를 억제하는 직접적인 증거로 판단된다. 
TTC는 조직내 탈수소효소(dehydrogenase)와 반응하여 정상조직은 붉은 색으로 관찰되나 허혈성 손상 조직에서는 탈수소효소가 소실되어 백색으로 염색되므로 비가역적 허혈 성 뇌손상의 유무를 관찰하는데 흔히 이용된다마. $\mathrm{tMCAO}$ 시 비가역성의 심한 허혈성 뇌손상, 즉 infarct이 형성 된 다 ${ }^{30,52)}$. 본 실험에서도 $\mathrm{tMCAO} 10$ 일 후 최종 부검 시 $\mathrm{tMCAO}$ 대조군에서는 TTC 염색 소견에서 대뇌피질의 국소 infarct 소견이 나타났으며, sham 대조군에 비해 유의성 있 는 $(\mathrm{p}<0.01)$ infarct volume의 증가가 나타났다. 그러나 본 실험에 사용한 세 용량의 모든 주작환(朱雀丸) 투여군에서 는 $\mathrm{tMCAO}$ 대조군에 비해 유의성 있는 $(\mathrm{p}<0.01)$ infarct volume의 감소가 투여 용량 의존적으로 나타나 주작환(朱 雀丸)이 허혈성 뇌손상에 대한 직접적인 보호 효과를 나타 내는 것으로 판단된다.

현재까지 수많은 연구들이 허혈성 뇌손상에 의해 초래되 는 infarct size의 변화에만 중점을 두고 후보물질의 약효를 평가해다 ${ }^{52,60,61)}$. 그러나 최근 들어, $\mathrm{MCAO}$ 모델에서 infarct size의 현저한 감소를 동반한 경우에도 허혈성 뇌손상에 의 해 초래되는 인지 및 행동장애에서는 별다른 변화가 관찰되 지 않는 경우가 빈번히 보고되고 있다 ${ }^{62,63)}$. 또한 일부 infarct volume에 영향을 미치지 않는 것으로 알려진 약물들 이 오히려 허혈성 뇌손상에 의해 초래되는 인지 및 행동장 애는 현저히 감소시킨다고 보고되는 등 ${ }^{63-66)}$ infarct volume과 인지 및 행동장애와의 상관관계를 명확히 해야 할 필요성이 대두되고 있어 적절한 신경학적 운동행동 및 인지 적 운동행동 검사의 필요성이 요구되고 있다. 이중 $\mathrm{limb}$ placing test는 대표적인 신경학적 운동행동 검사로 전지 및 후지의 배치 이상을 등급화 하여, 등급이 높을수록 심한 신 경학적 운동행동 이상을 나타낸다 ${ }^{26}$. 또한 body swing test 역시 빈번히 사용되는 신경학적 운동행동 검사로 ${ }^{27)}$ 정상동 물에서는 좌우측으로의 body swing이 대략적으로 $1: 1$ 인 반면, 허혈성 뇌손상이 있는 동물에서는 손상 부위로의 body swing이 현저히 감소되어 나타난다. Morris ${ }^{28)}$ 의 water maze test 는 대표적인 인지적 운동행동 검사로, 인지행 동 장애가 있는 경우 escape platform으로의 이동거리 및 시간이 현저히 연장되며, 특히 trial을 반복할 경우에도 이들 거리 및 시간의 감소가 현저히 억제 된다 ${ }^{52)}$. 본 실험의 결과, 주작환(朱雀丸)의 경구투여는 limb placing, body swing 및 water maze test에서 mild stroke 모델인 $\mathrm{tMCAO}$ 에 의
해 초래되는 신경학적 및 인지적 운동행동 이상 소견을 투 여 용량 의존적으로 현저히 억제하였다. 이러한 결과는 주 작환(朱雀丸)이 허혈성 뇌손상 백서에서 인지 및 운동기능 을 회복시키는 직접적인 증거로 판단된다.

본 연구의 결과, Lee 등 ${ }^{30)}$ 의 $\mathrm{tMCAO}$ 백서에서와 유사하 게 허혈성 뇌손상에 의해 초래된 infarct 주변부위에 현저한 대뇌피질의 위축이 초래되었으나, 주작환(朱雀丸)은 infarct 주변부위에 대뇌피질의 위축을 유의성 있게 $(\mathrm{p}<0.01)$ 억제 하였으며, 대뇌피질에서 단위 면적당 변성 신경원의 증가 역시 유의성 있게 $(\mathrm{p}<0.05)$ 억제하였다.

Caspase-3 및 PARP는 대표적인 apoptosis 마커로 ${ }^{67,68)}$, 대뇌피질에서 이들 caspase-3 및 PARP의 증가는 apopto$\mathrm{sis}$ 에 의한 뇌 손상의 증가를 의미하며, $\mathrm{tMCAO}$ 시에도 현저 한 대뇌피질내 caspase-3 및 PARP의 발현 증가가 잘 알려 져 있다 ${ }^{69,70)}$. 본 실험의 결과, 세 용량의 모든 주작환(朱雀 丸)의 경구투여는 $\mathrm{tMCAO}$ 에 의해 유발되는 대뇌피질에서 caspase-3 및 PARP 면역반응세포의 수적 증가를 유의성 있게 $(\mathrm{p}<0.05)$ 억제하였다. 따라서 주작환 (朱雀丸)의 구성 성분인 복신 ${ }^{17-19)}$, 침향 ${ }^{20-22)}$ 및 인삼 ${ }^{23-25)}$ 은 허혈성 뇌손상이 초래되는 인지 및 운동기능 장애에 매우 유효한 회복 효과 를 보인 것으로 판단된다.

이상에서, 주작환(朱雀丸)은 mild stroke 모델인 tMCAO 에서 허혈성 뇌손상에 따른 신경학적 및 인지적 운동행동 장애에 매우 유효한 효과를 나타내는 것으로 관찰되었다. 주작환(朱雀丸)은 복신(获神), 침향(沈香) 및 인삼(人垁) 등 3 종의 약재로 구성되어 있으며, 각 약재는 수많은 생리활성 물질을 함유하고 있어, 구성 약재 각각의 생리활성 성분의 검색과 더불어 금후 다양한 방면으로 기전적인 연구를 더 수행해야 할 것으로 판단된다.

\section{V. 결론}

$\mathrm{tMCAO}$ 로 유발한 일시적 국소 뇌허혈 유발 백서에 주작 환(朱雀丸)을 투여한 후 측정한 결과, 다음과 같은 결론을 얻었다.

1. 주작환(朱雀丸)은 모든 용량에서 $\mathrm{tMCAO}$ 7일 후부터 실험 전기간에 걸쳐 대조군에 비해 유의성 있는 체중의 증 가를 나타내었다.

2. 주작환(朱雀丸)은 모든 용량에서 tMCAO 7일 및 10일 
후에 대조군에 비해 유의성 있는 Forelimb placing test 점 수의 감소를 나타내었다.

3. 주작환(朱雀丸)은 모든 용량에서 $\mathrm{tMCAO}$ 7일 및 10일 후에 대조군에 비해 유의성 있는 Hindlimb placing test 점 수의 감소를 나타내었다.

4. 주작환(朱雀丸)은 모든 용량에서 $\mathrm{tMCAO}$ 3일 후부터 실험 전 기간에 걸쳐 대조군에 비해 유의성 있는 우측으로 의 body swing 횟수 및 비율의 증가를 투여 용량 의존적으 로 나타내었다.

5. 주작환(朱雀丸)은 모든 용량에서 $\mathrm{tMCAO} \mathrm{10일} \mathrm{후에}$ 대조군에 비해 유의성 있는 escape platform까지의 이동거 리 감소가 trial 2 및 3에서 나타났으며, 이동시간의 유의성 있는 감소 역시 모든 trials에서 투여 용량 의존적으로 나타 내었다.

6. 주작환(朱雀丸)은 모든 용량에서 대조군에 비해 유의 성 있는 infarct volume의 감소를 투여 용량 의존적으로 나 타내었다.

7. 주작환(朱雀丸)은 모든 용량에서 대조군에 비해 유의 성 있는 대뇌 피질 위축 억제 및 대뇌 피질내 변성 신경원, caspase-3 및 PARP 면역 반응세포의 수의 감소를 투여 용 량 의존적으로 나타내었다.

이상의 결과로 미루어 보아 주작환(朱雀丸)은 허혈성 뇌 손상에 따른 신경학적 및 인지적 운동행동 장애에 매우 유 효한 효과를 나타내었다.

\section{REFERENCES}

1. Feigin VL, Lawes CM, Bennett DA, Anderson CS. Stroke Epidemiology: A Review of Population-based Studies of Incidence, Prevalence, and Case-fatality in the Late 20th Century. Lancet Neurol. 2003;2:43-53.

2. Fisher M, Ratan R. New Perspectives on Developing Acute Stroke Therapy. Ann Neurol. 2003;53:10-20.

3. Green AR. Pharmacological Approaches to Acute Ischaemic Stroke: Reperfusion Certainly, Neuroprotection Possibly. Br J Pharmacol. 2008;153:S325-38.

4. Kirino T, Tamura A, Sano K. Selective Vulnerability of the Hippocampus to Ischemia Reversible and Irreversible Types of Ischemic Cell Damage. Progress in Brain Res. 1985;63:39-58.

5. Jung GS, Kim BH, Hwang WD. Effect of Chungpaesagan-tang on Cerebral Ischemic Damage Induced by MCAO in Rats. The Korean Journal of Oriental Preventive
Medicine. 2009;13:13-27.

6. Watanabe H, Zhao Q, Matsumoto K, et al. Pharmacological Evidence for Antidementia Effect of Choto-san (Gouteng-san), a Traditional Kampo medicine. Pharmacol Biochem Behav. 2003;75:635-43.

7. McCarty MF, Barroso-Aranda J, Contreras F. Potential Complementarity of High-flavanol Cocoa Powder and Spirulina for Health Protection. Med Hypotheses. 2010; 74:370-3.

8. Harada S, Hamabe W, Kamiya K, Satake T, Yamamoto J, Tokuyama S. Preventive Effect of Morinda Citrifolia Fruit Juice on Neuronal Damage Induced by Focal Ischemia. Biol Pharm Bull. 2009;32:405-9.

9. Zhang B, Tanaka J, Yang $L$, et al. Protective Effect of Vitamin E Against Focal Brain Ischemia and Neuronal Death through Induction of Target Genes of Hypoxia-inducible Factor-1. Neuroscience. 2004a;126:433-40.

10. Chang CY, Chen JY, Ke D, Hu ML. Plasma Levels of Lipophilic Antioxidant Vitamins in Acute Ischemic Stroke Patients: Correlation to Inflammation Markers and Neurological Deficits. Nutrition. 2005;21:987-93.

11. Ritz MF, Ratajczak P, Curin $Y$, et al. Chronic Treatment with Red Wine Polyphenol Compounds Mediates Neuroprotection in a Rat Model of Ischemic Cerebral Stroke. J Nutr. 2008;138:519-25.

12. Kim WC, Kim YS, Moon SK, et al. A Clinical Study of Vascular Dementia in Stroke Patients. The Journal of Korean Oriental Interna Medicine. 1998;19(2):50-9.

13. Yamaguchi S, Matsubara M, Kobayashi S. Event-related Brain Potential Changes after Choto-san Administration in Stroke Patients with Mild Cognitive Impairments. Psychopharmacology. 2004;171:241-9.

14. The Textbook Compilation Commitee of Neuropsychiatry of Oriental Medical Shools in Nation. The Neuropsychiatry of Oriental Medicine. Seoul: Jipmoon-Dang; 2011;33241.

15. Ann TW, Hong S, Kim HC. The Literatual Study on the Cerbral Vascular Dementia in Oriental and Occidental Medicine. The Journal of Oriental Medicine. 1996;2:4070.

16. Lee C. Introduction to Medicine. Seoul: Bubin Publisher; 2009;1892.

17. Hügel HM, Jackson N, May BH, Xue CC. Chinese Herbs for Dementia Diseases. Mini Rev Med Chem. 2012;12: 371-9.

18. Lin Z, Gu J, Xiu J, Mi T, Dong J, Tiwari JK. Traditional Chinese Medicine for Senile Dementia. Evid Based Complement Alternat Med. 2012;2012:692621.

19. Cai M, Shin BY, Kim DH, et al. Neuroprotective Effects of a Traditional Herbal Prescription on Transient Cerebral Global Ischemia in Gerbils. J Ethnopharmacol. 2011;138: 723-30.

20. Zhou M, Wang H, Suolangjiba, Kou J, Yu B. Antinociceptive and Anti-inflammatory Activities of Aquilaria 
Sinensis (Lour.) Gilg. Leaves Extract. J Ethnopharmacol. 2008;117:345-50.

21. Okugawa H, Ueda R, Matsumoto K, Kawanishi K, Kato A. Effect of Jinkoheremol and Agarospirol from Agarwood on the Central Nervous System in Mice. Planta Med. 1996;62:2-6.

22. Zhang Y, Wang W, Zhang J. Effects of Novel Anxiolytic 4-butyl-alpha-agarofuran on Levels of Monoamine Neurotransmitters in rats. Eur J Pharmacol. 2004b;504: 39-44.

23. Shi J, Tian JZ, Zhu AH, et al. The Influence of CGE on Expression of IL-1beta and C-fos Protein in the Hippocampus Region in Rats Following Cerebral Ischemiareperfusion. Zhongguo Zhong Yao Za Zhi. 2004;29: 570-5.

24. Zhang G, Liu A, Zhou Y, San X, Jin T, Jin Y. Panax Ginseng Ginsenoside-Rg2 Protects Memory Impairment via Anti-apoptosis in a Rat Model with Vascular Dementia. J Ethnopharmacol. 2008;115:441-8.

25. Lee MS, Yang EJ, Kim JI, Ernst E. Ginseng for Cognitive Function in Alzheimer's Disease: A Systematic Review. J Alzheimers Dis. 2009;18:339-44.

26. de Ryck M, van Reempts J, Borgers M, Wauquier A, Janssen PAJ. Photochemical Stroke Model: Flunarizine prevents Sensorimotor Deficits after Neocortical Infarcts in Rats. Stroke. 1989;20:1383-90.

27. Borlongan CV, Sanberg PR. Elevated Body Swing Test: A New Behavioral Parameter for Rats with 6-hydroxydopamine-induced Hemiparkinsonism. J Neurosci. 1995;15: 5372-8.

28. Morris RGM. Development of a Water Maze Procedure for Studying Spatial Memory in the Rat. J Neurosci Methods. 1984;11:47-60.

29. Longa EZ, Weinstein PR, Carlson S, Cummins R. Reversible Middle Cerebral Artery Occlusion without Craniectomy in Rats. Stroke. 1989;20:84-91.

30. Lee JY, Cho E, Ko YE, et al. Ibudilast, A Phosphodiesterase Inhibitor with Anti-inflammatory Activity, Protects Against Ischemic Brain Injury in Rats. Brain Res. 2012; 1431:97-106.

31. Sternberger LA. The Unlabeled Antibody Peroxidase-antiperoxidase (PAP) Method. In: Sternberger LA, ed. Immunocytochemistry. John Wiley \& Sons: New York; 1979;104-69.

32. Shi SR, Chaiwun B, Young L, Cote RJ, Taylor CR. Antigen Retrieval Technique Utilizing Citrate buffer or Urea Solution for Immunohistochemical Demonstration of Androgen Receptor in Formalin-fixed Paraffin Sections. J Histochem Cytochem. 1993;41:1599-604.

33. Ludbrook J. Update: Microcomputer Statistics Packages. A Personal View. Clin Exp Pharmacol Physiol. 1997;24: 294-6.

34. Holmes C. Dementia. Medicine. 2012;40(11):628-31.

35. Gainotti G, Marra C. Progress and Controversies in
Neuropsychology of Memory. Acta Neurol. 1992;14(4-6): $561-77$.

36. The Commitee of Cardiac Internal Medicine of Oriental Medical Shools in Nation. Cardiac Internal Medicine. Seoul: Seowon-Dang; 1999;425.

37. Bae OS. The Study of Constitutional Medicla on Senile Dementia. The Journal of Korean Oriental Medicine. 1992;13(2):101-6.

38. Ministry of Health \& Welfare. Nationalwide Study on the Prevalence of Dementia in Korean Elders. Seoul; 2008.

39. Mattson MP, Chan SL, Camandola S. Presenilin Mutations and Calcium Signaling Defects in the Nervous and Immune System. Bioessays. 2001;23(8):733-44.

40. Kling MA, Trojanowski JQ, Wolk DA, Lee VM, Arnold SE. Vascular Disease and Dementias: Paradigm Shifts to Drive Research in New Directions. Alzheimer's \& Dementia. 2012;1-12

41. Zhang Jie-bin. Jinyue's Complete Works. Seoul: Daesungmunhwa-Sa; 1988;692

42. Jin Sa-tak. Seokshilbirok. Seoul: Seowon-Dang; 1984; 102.

43. Jeon GH. Bianzhenggimun. Taipei:Gandhi publisher; 1990;222-5, 233-5.

44. Jung IC. The Study on Vascular Dementia Recorded in Chinese Medical Journal. The Journal of Daejeon Oriental Medicine. 2004;12:11-40.

45. The Textbook Compilation Commitee of Herbology of Oriental Medical Shools in Nation. Herbology. Seoul: Younglim-Sa; 2005; 348-9, 402, 575.

46. The Compilation Commitee of Encyclopedia of Chinse Herbal Medicine. Encyclopedia of Chinse Herbal Medicine. Seoul: Jungdam; 1998;3473-91,4379-84.

47. Krakovsky M, Polianski V, Nimrod A, Higazi A, Leker RR, Lamensdorf I. THR-18, a 18-mer Peptide Derived from PAI-1, is Neuroprotective and Improves Thrombolysis by tPA in Rat Stroke Models. Neurol Res. 2011;33:983-90.

48. Kuboyama K, Harada H, Tozaki-Saitoh H, Tsuda M, Ushijima K, Inoue K. Astrocytic P2Y(1) Receptor is Involved in the Regulation of Cytokine/chemokine Transcription and Cerebral damage in a Rat model of Cerebral ischemia. J Cereb Blood Flow Metab. 2011;31:1930-41.

49. Hunter AJ, Mackay KB, Rogers DC. To What Extent Have Functional Studies of Ischaemia in Animals Been Useful in the Assessment of Potential Neuroprotective Agents? Trends Pharmacol Sci. 1998;19:59-66.

50. Tamura A, Graham DI, McCulloch J, Teasdale GM. Focal Cerebral Ischaemia in the Rat, 1: Description of Technique and Early Neuropathological Consequences Following Middle Cerebral Artery Occlusion. J Cereb Blood Flow Metab. 1981;1:53-60.

51. Nishino H, Koide K, Aihara N, Kumazaki M, Sakurai T, Nagai H. Striatal Grafts in the Ischemic Striatum Improve Pallidal GABA Release and Passive Avoidance. Brain Res Bull. 1993;32:517-20. 
52. Roof RL, Schielke GP, Ren X, Hall ED. A Comparison of Long-term Functional Outcome after 2 Middle Cerebral Artery Occlusion models in Rats. Stroke. 2001;32:2648-57.

53. Nishino H, Czurko A, Fukuda A, et al. Pathophysiological Process after Transient Ischemia of the Middle Cerebral Artery in the Rat. Brain Res Bull. 1994;35:51-6.

54. Witte OW, Bidmon HJ, Schiene K, Redecker C, Hagemann G. Functional Differentiation of Multiple Perilesional Zones after Focal Cerebral Ischemia. J Cereb Blood Flow Metab. 2000;20:1149-65.

55. Koizumi J, Yoshida Y, Nakazawa T, Ooneda G. Experimental Studies of Ischemic Brain Edema. I: A New Experimental Model of Cerebral Embolism in Rats in which Recirculation Can Be Introduced in the Ischemic Area. Jpn J Stroke. 1986;8:1-8.

56. Chaudhary G, Sinha K, Gupta YK. Protective Effect of Exogenous Administration of Alpha-tocopherol in Middle Cerebral Artery Occlusion Model of Cerebral Ischemia in Rats. Fundam Clin Pharmacol. 2003;17:703-7.

57. Cui H, Lee JH, Kim JY, Koo BN, Lee JE. The Neuroprotective Effect of Agmatine after Focal Cerebral Ischemia in Diabetic Rats. J Neurosurg Anesthesiol. 2012;24: 39-50.

58. Nazam Ansari $M$, Bhandari U, Islam F, Tripathi $C D$. Evaluation of Antioxidant and Neuroprotective Effect of Ethanolic Extract of Embelia Ribes Burm in Focal Cerebral Ischemia/reperfusion-induced Oxidative Stress in Rats. Fundam Clin Pharmacol. 2008;22:305-14.

59. Kufemann IL. Principles of Neural Science. 2nd ed. New York: Elservier; 1986;806-15.

60. Nakayama H, Ginsberg MD, Dietrich WD. (S)-Emopamil, a Novel Calcium Channel Blocker and Serotonin S2 Antagonist, Markedly Reduces Infarct Size Following Middle Cerebral Artery Occlusion in the Rat. Neurology. 1988:38:1667-73.

61. Park CK, Nehls DG, Graham DI, Teasdale GM, McCulloch J. The Glutamate Antagonist MK-801 Reduces Focal
Ischemic Brain Damage in the Rat. Ann Neurol. 1988; 24:543-51.

62. Jaspers RM, Block F, Heim C, Sontag KH. Spatial Learning is Affected by Transient Occlusion of Common Carotid Arteries (2VO): Comparison of Behavioural and Histopathological Changes after '2VO' and 'Four-vesselocclusion' in Rats. Neurosci Lett. 1990;117:149-53.

63. Yamaguchi T, Suzuki M, Yamamoto M. YM796, a Novel Muscarinic Agonist, Improves the Impairment of Learning Behavior in a Rat Model of Chronic Focal Cerebral Ischemia. Brain Res. 1995;669:107-14.

64. Colbourne F, Corbett D. Delayed and Prolonged Post-ischemic Hypothermia is Neuroprotective in the Gerbil. Brain Res. 1994:654:265-72.

65. Kawamata T, Alexis NE, Dietrich WD, Finklestein SP. Intracisternal Basic Fibroblast Growth Factor (bFGF) Enhances Behavioral Recovery Following Focal Cerebral Infarction in the Rat. J Cereb Blood Flow Metab. 1996; 16:542-7.

66. Squire LR, Zola SM. Ischemic Brain Damage and Memory Impairment: A Commentary. Hippocampus. 1996;6:54652.

67. Nunez G, Benedict MA, Hu Y, Inohara N. Caspases: the Proteases of the Apoptotic Pathway. Oncogene. 1998; 17:3237-45

68. Barrett KL, Willingham JM, Garvin JA, Willingham MC. Advances in Cytochemical Methods for Detection of Apoptosis. J Histochem Cytochem. 2001;49:821-32.

69. Smrcka M, Horký M, Otevrel F, Kuchtícková S, Kotala V, Muzík J. The Onset of Apoptosis of Neurons Induced by Ischemia-reperfusion Injury is Delayed by Transient Period of Hypertension in Rats. Physiol Res. 2003;52: 117-22.

70. Ahmad A, Khan MM, Hoda MN, et al. Quercetin Protects Against Oxidative Stress Associated Damages in a Rat Model of Transient Focal Cerebral Ischemia and Reperfusion. Neurochem Res. 2011;36:1360-71. 